\author{
UNIVERSIDADE DE SÃO PAULO \\ FACULDADE DE FILOSOFIA, LETRAS E CIÊNCIAS HUMANAS \\ DEPARTAMENTO DE GEOGRAFIA \\ PROGRAMA DE PÓS-GRADUAÇÃO EM GEOGRAFIA HUMANA
}

PABLO KEHOMA COSTA SANTOS

RELAÇÕES ENTRE CARTOGRAFIA ESCOLAR E RACIOCÍNIO GEOGRÁFICO: ESTUDO DE CASO EM UMA ESCOLA DA REDE ESTADUAL DE SÃO PAULO

Versão Corrigida

São Paulo 


\author{
UNIVERSIDADE DE SÃO PAULO \\ FACULDADE DE FILOSOFIA, LETRAS E CIÊNCIAS HUMANAS \\ DEPARTAMENTO DE GEOGRAFIA \\ PROGRAMA DE PÓS-GRADUAÇÃO EM GEOGRAFIA HUMANA
}

PABLO KEHOMA COSTA SANTOS

\title{
RELAÇÕES ENTRE CARTOGRAFIA ESCOLAR E RACIOCÍNIO GEOGRÁFICO: ESTUDO DE CASO EM UMA ESCOLA DA REDE ESTADUAL DE SÃO PAULO
}

\author{
Versão Corrigida
}

Dissertação de Mestrado apresentada ao Programa de Pós-Graduação em Geografia Humana do Departamento de Filosofia da Faculdade de Filosofia, Letras e Ciências Humanas, da Universidade de São Paulo.

Orientador: Prof. Dr. Eduardo Donizeti Girotto.

São Paulo 
Autorizo a reprodução e divulgação total ou parcial deste trabalho, por qualquer meio convencional ou eletrônico, para fins de estudo e pesquisa, desde que citada a fonte.

Catalogação na Publicação

Serviço de Biblioteca e Documentação

Faculdade de Filosofia, Letras e Ciências Humanas da Universidade de São Paulo

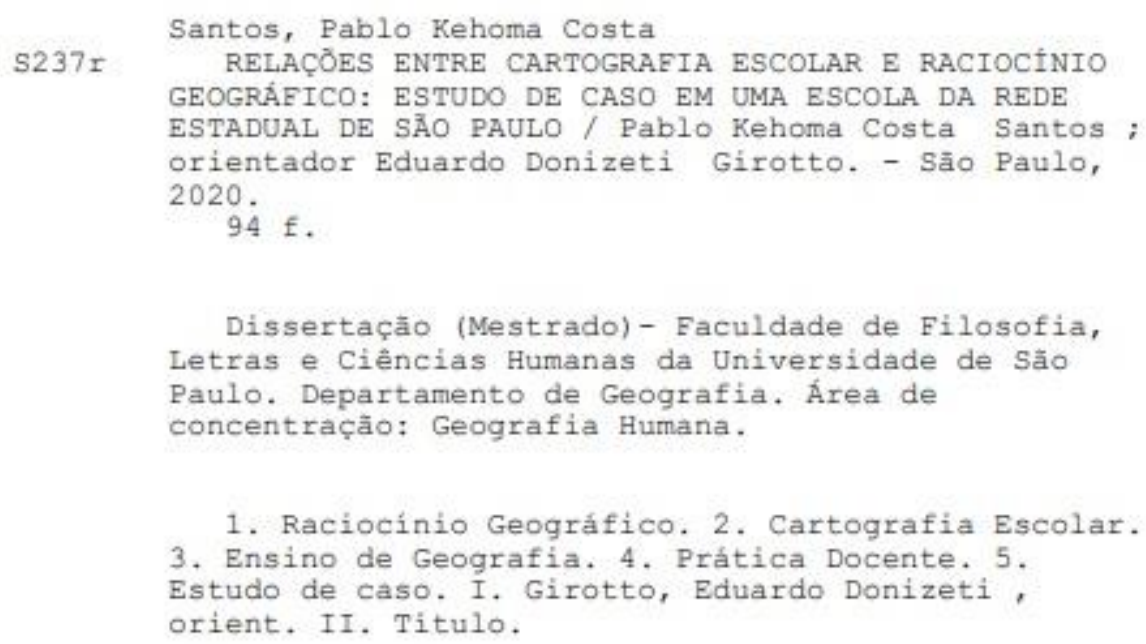




\section{ENTREGA DO EXEMPLAR CORRIGIDO DA DISSERTAÇÃO/TESE}

\section{Termo de Ciência e Concordância do (a) orientador (a)}

Nome do (a) aluno (a): Pablo Kehoma Costa Santos

Data da defesa: $12 / 08 / 2020$

Nome do Prof. (a) orientador (a): Eduardo Donizeti Girotto.

Nos termos da legislação vigente, declaro ESTAR CIENTE do conteúdo deste EXEMPLAR CORRIGIDO elaborado em atenção às sugestões dos membros da comissão Julgadora na sessão de defesa do trabalho, manifestando-me plenamente favorável ao seu encaminhamento e publicação no Portal Digital de Teses da USP.

São Paulo, 04/12/2020

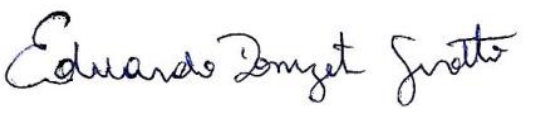

orientador (a) 


\section{RESUMO}

SANTOS, P.K. RELAÇÕES ENTRE CARTOGRAFIA ESCOLAR E RACIOCÍNIO GEOGRÁFICO: ESTUDO DE CASO EM UMA ESCOLA DA REDE ESTADUAL DE SÃO PAULO. Dissertação (Mestrado), Faculdade de Filosofia, Letras e Ciências Humanas, Universidade de São Paulo, 2020.

$\mathrm{O}$ presente trabalho discute as relações entre a cartografia escolar e 0 desenvolvimento do raciocínio geográfico. Partimos da premissa que os estudantes desenvolvem raciocínios geográficos antes de entrarem na escola, sendo que o ensino de geografia pode contribuir na ampliação de tais raciocínios, tendo a cartografia escolar como importante linguagem mediadora dos processos de ensino-aprendizagem. Em nossa perspectiva, raciocínios geográficos mais complexos são aqueles que possibilitam aos estudantes 0 entendimento da localização, distribuição e correlação de fenômenos espaciais, a partir da apropriação de conceitos e linguagens geográficas e da articulação de variáveis em diferentes escalas espaço-temporais. Para avaliar esta relação entre cartografia escolar e raciocínios geográficos, foram elaboradas situações de aprendizagem para alunos do sexto ano do Ensino Fundamental da Escola Estadual José Chediak, localizada na zona leste da cidade de São Paulo. A sequências foram desenvolvidas entre abril e outubro de 2019. Os resultados reforçaram a premissa de que os estudantes já desenvolvem raciocínios geográficos antes de entrarem na escola, uma vez que já construíam hipóteses e argumentos, a partir duas vivências, para entender os desafios e problemas propostos nas aulas. Com o desenvolvimento das situações de aprendizagem, mediadas pela linguagem cartográfica muitos estudantes conseguiram construir interpretações complexas da realidade, correlacionando mais de duas variáveis e utilizando conceitos geográficos. Além disso, foi possível verificar que raciocínio geográfico e a cartografia escolar mantem uma relação dialética e não dual. A apropriação da linguagem cartográfica contribui para o desenvolvimento de raciocínios geográficos mais complexos que, por sua vez, possibilitam novas apropriações e usos da linguagem cartográfica.

Palavras-chave: Cartografia, Escola, Raciocínio Geográfico. 


\begin{abstract}
SANTOS,P.K. RELATIONSHIPS BETWEEN SCHOOL CARTOGRAPHY AND GEOGRAPHICAL REASONING - CASE STUDY IN A SCHOOL IN THE STATE OF SÃO PAULO. Thesis (Master's), Faculdade de Filosofia, Letras e Ciências Humanas, Universidade de São Paulo, 2020.
\end{abstract}

The present work discusses the contributions that school cartography has to the development of geographic reasoning. We start from the premise that students develop geographic reasoning before entering school, and the teaching of geography can contribute to the expansion of such reasoning, with school cartography as an important mediating language of the teaching-learning processes. In our perspective, more complex geographic reasonings are those that enable students to understand the location, distribution and correlation of spatial phenomena, based on the appropriation of geographical concepts and languages and the articulation of variables at different spatiotemporal scales. To assess this relationship between school cartography and geographic reasoning, learning situations were developed for students in the sixth year of elementary school at the José Chediak State School, located on the east side of the city of São Paulo. The sequences were developed between April and October 2019. The results reinforced the premise that students already develop geographic reasoning before entering school, since they already built hypotheses and arguments, starting from two experiences, to understand the challenges and problems proposed in classes. With the development of learning situations, mediated by the cartographic language, many students were able to build complex interpretations of reality, correlating more than two variables and using geographical concepts. In addition, it was possible to verify that geographic reasoning and school cartography maintain a dialectical and not a dual relationship. The appropriation of cartographic language contributes to the development of more complex geographical reasoning, which, in turn, enables new appropriations and uses of cartographic language.

Keywords: Cartography, School, Geographic reasoning 


\section{LISTA DE FIGURAS}

Figura 1: Cartografia No Ensino Fundamental

Figura 2- Conteúdos E Habilidades

Figura 3: Cartografia Na Bncc

Figura 4: Cartografia No Currículo Paulista

Figura 5: Localização Da Pesquisa

Figura 6- Mapa Do Brasil: Grandes Regiões

Figura 7: Símbolos Qualitativos E Quantitativos

Figura 8: Mapa Baía De Guanabara

Figura 9: Bloco Diagrama

Figura 10: Mapa Hipsómetrico Da Cidade De São Paulo

Figura 11: Mapa Regiões E Distritos Da Cidade De São Paulo

Figura 12: Manchete Da Matéria- Chuva Em São Paulo

Figura 13: Avenida Alagada 


\section{LISTA DE GRÁFICOS}

Gráfico 1: Qual A Melhor Forma De Sair Da Floresta E Encontrar O Caminho De Volta.

Gráfico 2: Elementos Do Mapa

Gráfico 3:Tipo De Representação Da Figura A

Gráfico 4: É Possível Observar Áreas De Risco Nas Figuras A E B.

Gráfico 5: O Que Faz Os Terrenos Terem Valores Diferentes

Gráfico 6: Área Que Tem Maior Probabilidade De Apresentar Problemas

Gráfico 7: Principais Problemas 
À minha mãe, Maria de Lourdes Santana Costa, razão de todo o meu esforço e desejo de aprender. 


\section{AGRADECIMENTOS}

Durante todo esse trajeto no mestrado, vários foram os momentos que a dificuldade gritava alto, e a vontade de desistir me visitava, mas quando se tem um sonho, por mais árduo que seja o caminho, a gente resiste, passa por cima das dores, e segue em frente, para a conquista. Dessa maneira, eu expresso aqui a minha gratidão a todas as pessoas que me ajudaram a prosseguir nesses três anos, que foram bastante intensos.

Agradeço a Deus, por me permitir a realização deste sonho, e por me fortalecer na caminhada, dando-me sabedoria, força e o discernimento necessário para avançar em cada etapa!

À minha mãe, Maria de Lourdes, que é a minha base, e inspiração! Esse trabalho é a forma como consigo te agradecer por ter se esforçado para me dar sempre o seu melhor! Eu jamais poderei retribuir tal feito, obrigado por ser a melhor mãe do mundo, por cuidar tão bem de mim, e por me incentivar a não desistir das minhas metas, mesmo naqueles momentos mais difíceis! Te amo!

Agradeço ao meu pai João Roberto, e aos meus irmãos Cláudio, João Pedro e Ana Terra, pelo incentivo e carinho.

Agradeço a Maik, por me aguentar nos momentos de intenso stress, e por sempre estender a mão, me auxiliando e dando o apoio necessário para prosseguir nesta jornada.

A todos os meus familiares e amigos, que aqui não citei, deixo também a minha gratidão, pois sei que são parte dessa minha trajetória!

Toda a minha gratidão ao meu orientador Eduardo Donizeti Girotto, que me auxiliou, possibilitando a abertura de novos caminhos, e colaborou com a minha formação nesta caminhada de intensos estudos.

Agradeço a minha amiga de mestrado Bruna, que foi a pessoa que mais me socorreu nos momentos de cansaço, e de angústias, dando-me forças e ajudando nas dificuldades; ainda bem que nos conhecemos!

Á Universidade de São Paulo, por me possibilitar vivenciar anos de aprendizagem, em um ambiente que antes, parecia estar tão distante, mas que se tornou um espaço de inúmeras contribuições. Sou imensamente grato as 
oportunidades de discutir o papel da educação, bem como os caminhos para que ela se efetive na vida dos sujeitos.

Agradeço aos meus alunos da Escola Estadual José Chediak, por me inspirarem todos os dias, permitindo que a sala de seja um espaço de intenso aprendizado e desenvolvimento humano. Vocês são a causa da realização deste estudo! Obrigado por me desafiarem a ser melhor, e por me inspirarem a criar estratégias para que a aprendizagem de vocês, tenha sentido.

Aos meus professores, que durante toda a minha trajetória como estudante foram inspiração para seguir aprendendo, deixo a minha gratidão.

As minhas alunas para a vida toda, Isabela Mazuchini e Giovanna Lima, a minha imensa gratidão. Vocês são inesquecíveis!

A todos e todas, que de maneira direta e indireta me fortaleceram neste processo, deixo também os meus agradecimentos. 
Eu sou de remar, sou de insistir, mesmo que sozinho.

(Vista Pro Mar- Silva/ Lucas Silva) 


\section{SUMÁRIO}

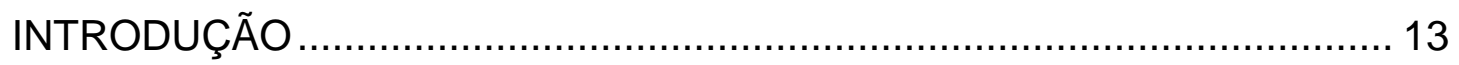

1. O RACIOCÍNIO GEOGRÁFICO: PREMISSAS CONCEITUAIS .............. 18

2. A CARTOGRAFIA ESCOLAR: PREMISSAS CONCEITUAIS ................ 23

3. RACIOCÍNIO GEOGRÁFICO E CARTOGRAFIA: REVISÃO DA

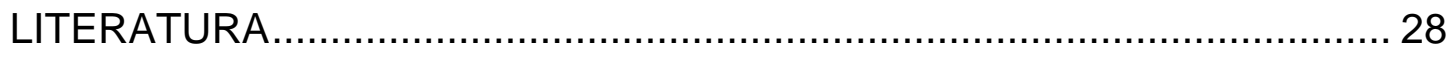

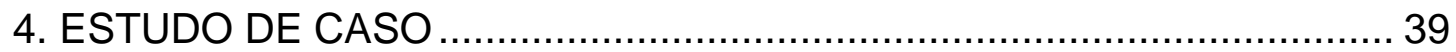

4.1. SITUAÇÃO DE APRENDIZAGEM 1 - Orientação Geográfica ............... 44

4.2 SITUAÇÃO DE APRENDIZAGEM 2- Os Elementos do Mapa...................51

4.3 SITUAÇÃO DE APRENDIZAGEM 3. Perfil topográfico e as representações tridimensionais do espaço geográfico. .................................58

4.4 SITUAÇÃO DE APRENDIZAGEM 4- MAPA HIPSOMÉTRICO DA

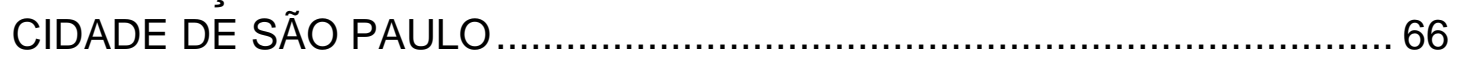

4.5 SITUAÇÃO DE APRENDIZAGEM 5: A Geografia: uma lente para ler o

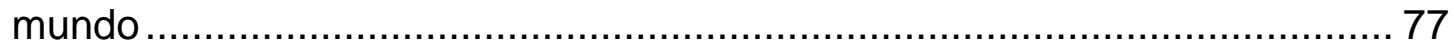

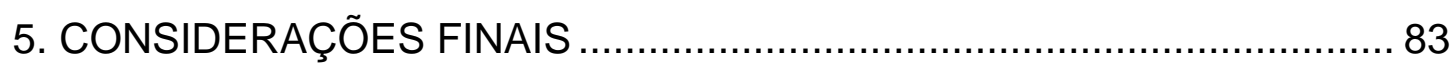

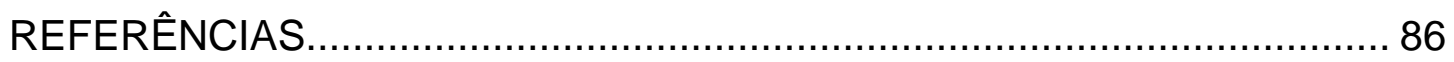




\section{INTRODUÇÃO}

O desejo por pesquisar educação e cartografia nasceu a partir das minhas experiências na graduação na Universidade Estadual da Bahia, Campus VI, na cidade de Caetité entre os anos 2009 e 2013.

Durante a graduação, a vontade de pesquisar a Cartografia Escolar apareceu a partir das aulas de cartografia temática, se intensificando com a minha entrada no Programa Institucional de Bolsa de Iniciação à Docência (PIBID). Neste programa, foi possível estar mais perto da sala de aula, entender seu funcionamento, bem como buscar estratégias que fossem capazes de criar um ambiente favorável a aprendizagem, e que fugisse dos lugares comuns, muitas vezes presentes no cotidiano escolar e que pouco fazem sentido aos estudantes e docentes.

O trabalho de conclusão de curso, realizado na graduação, apontou para esse caminho. Nele abordei o uso de novas tecnologias no ensino de cartografia, focando na alfabetização cartográfica. Assim, a vontade de seguir pesquisando foi crescendo e a cada novo contato com a sala de aula e com o tema as ideias iam se formando e amadurecendo, dando as condições para a elaboração de um possível projeto de pesquisa para ingresso na pós-graduação.

O PIBID colocou-me em contato com autores, que discutiam o tema da Cartografia Escolar, bem como seu desenvolvimento na escola, levando-me a refletir sobre o tema, e articular, junto a outros professores, estratégias para trabalhar os conceitos de maneira que houvesse uma maior participação dos alunos.

Desta forma, após me mudar para o Estado de São Paulo, no final de 2013 e, em seguida, me efetivar como professor da rede estadual de ensino, a vontade de continuar os meus estudos na área permaneceu, até o momento que me senti motivado a escrever um projeto de pesquisa para tentar ingresso no curso de pós-graduação da Universidade de São Paulo.

Entrar para este programa é, para mim, uma grande realização pessoal e profissional, pois de onde venho, as oportunidades são escassas e chegar neste espaço de aprendizagem e produção de conhecimento é uma grande conquista, 
pois me proporciona condições de amadurecimento e amplitude do conhecimento no que se refere ao Ensino de Geografia.

Sendo assim, este estudo visa ampliar as possibilidades que existem na aprendizagem de Geografia, buscando, a partir do cotidiano escolar, maneiras de desenvolver o Raciocínio Geográfico com o auxílio da Cartografia presente na escola. Assim, o objetivo central desta pesquisa é compreender como a Cartografia Escolar auxilia no desenvolvimento do raciocínio geográfico.

Partindo deste pressuposto, os procedimentos pautam-se na análise do ensino cartográfico em sala de aula, sendo que a pesquisa foi realizada em minhas aulas de Geografia. Para tanto, desenvolveu-se situações de aprendizagem que visaram possibilitar aos estudantes condições de pensar sobre situações do seu cotidiano, e resolvê-las a partir dos conhecimentos geográficos, desenvolvendo, o que aqui conceituamos de Raciocínio Geográfico.

Na pesquisa, foram aplicadas cinco situações de aprendizagem, em três turmas de sexto ano do Ensino Fundamental, na Escola Estadual José Chediak, localizada no Parque São Lucas, Zona Lesta da cidade de São Paulo, no ano de 2019, totalizando 110 alunos participantes. As situações de aprendizagem tiveram o objetivo de perceber de que maneira a cartografia escolar colabora com o desenvolvimento do raciocínio geográfico, bem como analisar possibilidades de aperfeiçoamento das sequências didáticas propostas em um processo contínuo de reflexão sobre e a partir da prática docente. Consideramos esta relação entre reflexão e ação essencial no processo de formação contínua de professores, em especial, ao possibilitar a articulação entre os conhecimentos teórico-conceituais e aqueles constituídos no contexto profissional. A base para a construção das sequências didáticas desenvolvidas foram as proposições apresentadas por Passini (2012), que buscam desenvolver no sujeito essa habilidade de ler o mundo a partir dos conhecimentos geográficos, auxiliado pela linguagem cartográfica.

Metodologicamente, a pesquisa se assenta em duas perspectivas. De um lado, trata-se de um estudo de caso pois,

[...]sua característica mais distinta está na ênfase na singularidade, no particular. Isso implica que o objeto de estudo 
seja examinado como único, uma representação singular da realidade, realidade está multidimensional e historicamente situada. (ANDRÉ, 1984,p.52)

O estudo de caso apresenta uma estratégia de pesquisa bastante utilizada nas Ciências Sociais e pode ser utilizado como método para a pesquisa em educação, pois possibilita refletir as práticas, bem como as dificuldades quando se pretende conhecer o "como?" e o "por quê?" os fenômenos acontecem (YIN, 2001).

É importante ressaltar que o estudo de caso pode-se ser utilizado para desenvolver vários objetivos, já que o caso, geralmente, envolve algumas situações do cotidiano escolar, e assim, fica suscetível a ter várias interpretações pelos sujeitos. Ele também pode desenvolver a capacidade de análise dos sujeitos, colaborando com a formação de novos conceitos, com base nas reflexões que vão surgindo por meio das situações de aprendizagem, colaborando assim, com a ampliação de seu vocabulário geográfico e capacidade de reflexão diante dos temas apresentados.

Além disso, é importante ressaltar que se trata também de uma pesquisa participante, pois ela, como afirma (BRANDÃO, 1981): não é somente uma ferramenta de pesquisa, [é tida também] como uma postura, na compreensão de uma maneira diferente de se conceber o fazer científico.

Partindo deste pensamento, pode-se entender que por meio da pesquisa participante, é possível estudar de maneira dinâmica as dificuldades que vão surgindo como resposta a pesquisa e, também, como ela colabora com o suprimento das necessidades apontadas, ao passo que considera a realidade investigada e seus sujeitos.

Sendo assim, (BRANDÃO, 1985): ajuda a compreender que "nessa caminhada o pesquisador coloca-se como sujeito, juntamente com o grupo interessado, e a serviço não do grupo mas da prática política daquele grupo".

Diante disso é possível compreender que, todas as situações de aprendizagem aplicadas durante o processo da pesquisa serviram para colaborar na reflexão do que estava sendo abordado, bem como a maneira que as próximas situações seriam pensadas para aqueles sujeitos que estavam no meio do processo de aprendizagem no cotidiano escolar. Além disso, a reflexão sobre os resultados do desenvolvimento das sequências possibilitou ações para 
aperfeiçoamento das minhas práticas, constituindo-se, assim, em um processo de formação contínua docente desde o cotidiano escolar.

Nos capítulos que se seguem faremos uma introdução aos conceitos de Cartografia Escolar e Raciocínio Geográfico através de reflexões e levantamento bibliográfico amplo, que colaborou com a construção dos conceitos, abordando em seguida as reflexões acerca do tema dentro da pesquisa realizada em sala de aula. Dessa forma, o primeiro capítulo tem o objetivo de discutir o raciocínio geográfico, e suas definições a partir de autores como: Paul Claval, Delgado de Carvalho, Yves Lacoste, Paulo César da Costa Gomes, entre outros. Esses autores trouxeram uma grande contribuição na compreensão da maneira como o raciocínio geográfico está presente na vida dos sujeitos, muito antes de estar presente na escola, como conhecimento institucionalizado, bem como suas potencialidades quando inserido no contexto escolar.

O segundo capítulo apresenta a cartografia escolar, bem como suas definições e potencialidades no ensino de Geografia, ressaltando a importância dessa linguagem no processo de compreensão do espaço. Diante disso é também proposto o conceito de alfabetização cartográfica e suas contribuições no desenvolvimento dos processos de ensino-aprendizagem de geografia.

O terceiro capítulo aponta algumas reflexões sobre os estudos atuais no campo do raciocínio geográfico e suas relações com a cartografia escolar, bem como suas contribuições para o desenvolvimento dessas habilidades na escola, e a partir destes estudos, surgem os apontamentos, com as colaborações da minha pesquisa neste campo.

O quarto capítulo apresenta o estudo de caso, bem como a pesquisaação, que apresenta as situações de aprendizagem aplicadas, e as discussões dos resultados que foram surgindo ao longo do percurso, focando nas possibilidades de compreender o lugar, através das atividades que abordam a cidade de São Paulo e, em alguns momentos, outras cidades do Brasil, pensando sempre nas possibilidades de desenvolvimento do raciocínio geográfico através das reflexões realizadas.

Por último, o estudo é concluído através de reflexões que se constituíram ao longo de todo o processo, bem como suas implicações no cotidiano escolar 
e na vida dos sujeitos que estiveram presentes, e foram alvo das investigações aqui apresentadas, bem como as mudanças que puderam acontecer, ao longo do trajeto nas práticas que foram desenvolvidas na sala de aula. 


\section{O RACIOCÍNIO GEOGRÁFICO: PREMISSAS CONCEITUAIS}

A capacidade que os sujeitos têm de observar o espaço a sua volta, e encontrar soluções para suas questões, pode ser percebida ao longo de todas as civilizações.

A observação que os primeiros homens faziam do lugar onde habitavam, deu a eles condições de se desenvolverem enquanto sociedade, e de se firmarem em lugares diversos, com condições físicas completamente diferentes. Dentre esses aspectos pode-se citar a observação das condições climáticas e o movimento dos rios. Essas observações foram essenciais para a sobrevivência e manutenção de alguns povos em todos as regiões do mundo.

Todas essas questões nos levam a pensar sobre a presença da Geografia na vida dos sujeitos. Esse conhecimento, ainda não instituído como um campo científico, o que só irá ocorrer no século XIX, já está, assim, imerso na vivência de diferentes grupos humanos, expressos em suas vivências espaciais. Segundo Claval,

Desde a origem dos tempos, todo homem é geografo. Ele o segue sendo, ainda hoje. A geografia não faz nascer curiosidades, nem ensina atitudes, habilidades, ou conhecimentos que teriam ficado desconhecidos até a sua aparição. (CLAVAL,2010,p.11)

Isto nos faz entender que olhar geograficamente não é um privilégio que as ciências modernas nos deram, pois segundo (GOMES, 2017, p.13) "a Geografia é uma forma de pensar. Ela também é uma maneira original e potente de organizar o pensamento".

Sendo assim, podemos compreender que a geografia enquanto forma de pensar e agir, já estava presente na vida dos sujeitos antes mesmo dela se institucionalizar como ciência e como disciplina escolar. Esta forma de pensar, baseada nos estudos de Gomes (2017), vai se dividir em três domínios do conhecimento, que nos ajudam a compreender a maneira como a Geografia se apresenta como um saber inerente a vida dos sujeitos.

No primeiro domínio, a Geografia está ligada a capacidade de, segundo Gomes (2017, p.17) "situar as coisas no espaço, e de nos situarmos nele", ou seja, a capacidade de se orientar espacialmente. A necessidade de encontrar 
algo para manter a sua sobrevivência faz com que essa capacidade geográfica esteja presente na vida dos sujeitos.

Outra maneira de perceber a Geografia é através da cultura, que vai se formando através de ligações e reflexões, fazendo com que esse conhecimento se torne uma maneira de viver e organizar o espaço. Por isso,

$\mathrm{Na}$ espécie humana, o desenvolvimento da cultura faz essa inteligência espacial compor um conjunto de conhecimentos que são estabilizados e transmitidos. Desde os mais primitivos e recuados agrupamentos humanos, temos o desenvolvimento de comportamentos espaciais aos quais podemos atribuir o nome de Geografia. (GOMES, 2017, p.18)

Esse desenvolvimento está ligado a necessidade que os sujeitos têm de sobreviver e, para isso, eles precisam responder uma simples questão: Onde? A partir da resposta a essa questão é possível então, fazer ligações que sejam capazes de auxiliar a sua sobrevivência, e assim, esses conhecimentos vão se difundido em cada cultura mediante as suas necessidades. Colaborando com o entendimento de que "para um fenômeno merecer o qualificativo de geográfico, é necessário que o fato posição ou situação, o venha diferenciar (CARVALHO, 1945, p.8)". Assim, no momento em que surge a pergunta: Onde? Já se pode começar a mover as engrenagens para pensar a sua posição, e tentar compreender por que este acontecimento se dá ali, e não em outro lugar, esse movimento faz com que o raciocínio utilizado seja permeado pela Geografia.

A outra forma que a Geografia se apresenta, segundo Gomes (2017, p.19) é como "campo ou área de interesse que reúne inúmeras tradições, todas preocupadas em responder à questão do porquê das lógicas das localizações". Esta é a Geografia institucionalizada como ciência e disciplina escolar, que carrega seu arcabouço filosófico, efetivando seus conceitos e temas, bem como seus procedimentos de pesquisa.

Esses caminhos apontados por Gomes (2017) nos permitem refletir então, que a Geografia, antes mesmo de ser um conhecimento organizado, já estava presente na vida dos homens, sendo um conhecimento fundamental para manutenção da vida, e dessa forma, imprescindível para o seu desenvolvimento.

Assim, pode-se pensar que, segundo Claval (2010), o conhecimento geográfico vai se construindo, e se faz mais presente "como prática e habilidade, 
do que propriamente como um saber sistematizado". Utilizar esses conhecimentos geográficos para se localizar, compreender o espaço e organizálo pode ser então entendido como raciocínio geográfico. E vamos então compreendendo que este raciocínio geográfico não é exclusividade da Geografia escolar, mas uma maneira de organização do pensamento, que se faz presente na vida dos sujeitos, compondo suas histórias e cotidianos, como um forte auxílio para o seu desenvolvimento.

Cabe, então, algumas questões: de que maneira a escola pode contribuir no desenvolvimento deste raciocínio? Quais caminhos podem ser traçados para que ele seja intencionalmente estimulado?

Podemos pensar esse desenvolvimento do raciocínio geográfico passando por três fatores básicos: a capacidade dos sujeitos de produzirem explicações sobre os fenômenos da realidade, destacando a sua dimensão espacial, o que significa entender sua localização, distribuição e as possíveis correlação de tais fenômenos. Isso significa, entre outras coisas, entender onde esses fenômenos acontecem, as dimensões espaço-temporais alcançam e todos os possíveis agente envolvidos na sua realização, ou seja, processos que nos ajudam a raciocinar geograficamente uma determinada situação, e compreendê-la.

No entanto, é fundamental destacar que o raciocínio geográfico é, também, um conhecimento estratégico e, portanto, alvo de disputas em torno do seu acesso e disseminação. Como aponta Lacoste,

É por essas razões que, desde séculos, as classes dirigentes fazem constituir cartas em diferentes escalas, para ter uma ideia precisa da complexidade dos territórios sobre os quais se exerce seu poder e aqueles sobre os quais poderia se projetar a articulação dos diferentes níveis de análise, efetuando-se empiricamente pela ação e a prática do poder.( LACOSTE,P.93)

Assim, é possível compreender que o conhecimento geográfico e a maneira como ele colabora com o desenvolvimento de raciocínios cada vez mais complexos dos sujeitos é estratégico, e utilizado a fim de beneficiar e perpetuar a ordem política e econômica que segrega e causa as desigualdades que se apresentam em nossa sociedade. 
Desta maneira, é importante que este conhecimento geográfico, e todos os processos que promovem o raciocínio geográfico, se faça presente na vida dos sujeitos, pois como afirma Lacoste (1988,p.93), "um saber para os ajudar a pensar o espaço se toma cada vez mais necessário, pois que eles não podem se guiar pela prática do poder". Quando os diferentes sujeitos entram em contato como esse saber, a maneira de enxergar a realidade muda, bem como a percepção que eles têm da influência global sob o lugar em que vivem.

Este saber colabora diretamente com a compreensão do lugar, entendido aqui como resultado de processos que articulam agentes em diferentes escalas espaço-temporais. Como reforça Lacoste (1988, p.94) "é preciso fazer com que as pessoas compreendam que, quando elas estão num lugar, elas não estão num único compartimento, numa única região". Dessa maneira o raciocínio geográfico vai colaborar com essa leitura mais crítica do espaço, possibilitando uma compreensão multiescalar dos fenômenos e seus agentes, bem como seus impactos no lugar de cada sujeito.

Para ajudar os cidadãos ali onde eles vivem a tomar consciência das causas fundamentais que determinam o agravamento das contradições que eles sofrem diretamente é preciso, primeiro, fazer a análise em termos concretos e precisos dessas contradições tais como elas se manifestam ao nível local, sobre os locais de trabalho e da vida cotidiana, sem esquecer as condições ecológicas, que são, frequentemente, um fator de agravamento. (LACOSTE, 1988, p.95)

Sendo assim, pode-se pensar que a escola seja o lugar onde o raciocínio geográfico vai ganhando possibilidades para se aprimorar, sendo um dos caminhos para conscientização dos sujeitos. Assumindo que o raciocínio geográfico não é um saber produzido exclusivamente pela escola, enfrentamos o desafio de pensar e propor como ele pode ser potencializado no espaço escolar, concebido também como parte da organização da vida dos sujeitos. A produção de raciocínios geográficos cada vez mais complexos, correlacionando, multiescalarmente, diferentes fenômenos, processos e agentes, pode fornecer possibilidades aos sujeitos de pensarem as influências que sofrem pelas forças do Estado, das firmas e organismos transnacionais e assim, podem aprender a se perceberem como sujeitos capazes de ler o mundo a partir do lugar onde vivem. 
Sendo assim, a escola vai colaborar com a construção, e auxiliar na produção de um raciocínio Geográfico que possibilite aos alunos pensarem o espaço, para que consigam nele se organizarem, e assim buscar combater as desigualdades tão presentes em seus cotidianos, pois,

O raciocínio geográfico, por força da sua pergunta fundadora por que isso está onde está? -, é levado a conectar elementos muito diversos que são necessariamente tomados juntos pelo fato de ali se apresentarem. (GOMES, 2017, p.145)

Desse modo, a escola, pode ser um espaço de ampliação e compreensão dessa pergunta fundadora, pois ela não é uma questão simples, como aparenta ser. Ao contrário, traz em sua resposta uma complexidade de fatores que podem ser bem desenvolvidos se as categorias, conceitos, conteúdos e linguagens básicos da Geografia estiverem presentes, auxiliando na formação desta leitura de mundo pelos estudantes.

Tal leitura, em diálogo com Freire (2005) tem como ponto de partida o lugar de vivência dos estudantes e pressupõe movimentos de idas e vindas, de distanciamentos e aproximações, mediados por proposições e recursos didáticos. Como isso, vai possibilitando aos estudantes compreender a escala global de acontecimentos, ajudando-o a perceber que os fatos não acontecem de maneira isolada.

Assim, os conteúdos e as categorias da Geografia, se tornam os meios para compreender as situações vividas, e não mais as razões centrais do aprender. Dessa forma, a realidade de cada um se torna o ponto de partida para essas reflexões e, consequentemente, das aprendizagens que se darão no espaço escolar, através da formação do raciocínio geográfico.

Neste processo, a linguagem cartográfica também ganha bastante importância, pois sabemos que ela será a maneira como os fenômenos serão representados. Para tanto, no próximo capítulo, abordaremos as definições de cartografia escolar, bem como seus aspectos gerais, desde a alfabetização cartográfica, até por fim, a sua relação com o raciocínio geográfico. 


\section{A CARTOGRAFIA ESCOLAR: PREMISSAS CONCEITUAIS}

Para auxiliar as discussões sobre a cartografia escolar, suas definições, bem como os seus desdobramentos na vida dos sujeitos, foram utilizados autores como: Martinelli (1998), Oliveira (2007), Petchenik (1995), Simielli (2007), Lacoste (1988), Katuta (1997). Tais autores e autoras trazem importantes contribuições e reflexões que auxiliam na compreensão das potencialidades da cartografia escolar no desenvolvimento do raciocínio geográfico e, consequentemente, na forma como o sujeito irá ler o mundo.

A cartografia é definida por Joly (1990, p. 07) como a "[...] a arte de conceber, de levantar, de redigir e de divulgar mapas". Por estar diretamente ligada a Geografia, permite representar o espaço. Dessa maneira, pode-se pensar que a linguagem cartográfica possibilita ao sujeito desenvolver a capacidade de perceber, através de símbolos, partindo inicialmente do seu lugar de vivência para a compreender o espaço como um todo. Sendo assim, a utilização de tal linguagem cartográfica faz com que esse processo se torne indispensável para atingir os níveis necessários à construção do saber geográfico e, consequentemente, aprimorar os processos de ensinoaprendizagem em Geografia na direção do raciocínio geográfico.

Segundo Lacoste (1988), as representações do espaço não fazem sentido se as pessoas não conseguem fazer a leitura delas. Essas leituras são importantes, pois colaboram com a capacidade dos sujeitos de se tornarem autônomos e entenderem o espaço que vivem e a lógica que vai determinar a sua criação e transformação ao longo do tempo.

Apesar de Joly (1990) afirmar que a linguagem cartográfica é universal, exigindo pequena iniciação, sua aprendizagem na escola deve ser gradativa, respeitando a capacidade que o aluno tem de assimilar e construir conteúdos e conceitos. Apesar de os mapas e os atlas estarem, quase sempre, relacionados à escola, mais especificamente ao ensino de Geografia, o desses recursos, fundamentais à linguagem cartográfica, ainda é pequeno no ambiente escolar. Ainda assim o mapa é o recurso da linguagem cartográfica mais presente na sala de aula. Como aponta Souza e Katuta, "quase todas as representações cartográficas utilizadas no ensino de Geografia são mapas, exceção feita 
àquelas que representam graficamente espaços mais próximos do real" (SOUZA e KATUTA, 2001, p.110).

Para de fato entendermos como o mapa tem sido utilizado nas aulas de Geografia, é necessário indagar: o que seria um mapa? Segundo Joly, um "mapa é uma representação geométrica plana, simplificada e convencional, do todo ou de parte da superfície terrestre, numa relação de similitude denominada escala" (JOLY, 1990, p.7). Para este autor, mapa vem a ser a representação de toda ou de parte da superfície da Terra. Tal representação ainda precisa ser plana e guardar uma proporção com o objeto que está sendo representado. Joly (1990) reconhece o mapa como técnica. Neste caso, o autor não leva em conta as questões ligadas a escala, sendo sua finalidade apenas a diferenciação entre mapas e cartas, uma vez que a escala do mapa é menor que a da carta. O autor também não se preocupa em definir o papel do leitor do mapa, pois ao definir a leitura do mapa como técnica para lê-lo torna-se necessário seguir as regras básicas de observação do mesmo, não levando em conta realidades individuais de interpretação e as capacidades cognitivas de cada sujeito e, em especial, dos alunos. Dessa forma,

Seria fundamental que na escola os documentos cartográficos fossem utilizados não somente como fontes de leitura, mas também de uso e interpretação. O mapa não foi construído apenas para ser lido, mas para ser interpretado, discutido e principalmente utilizado cotidianamente na vida do homem adulto moderno. (OLIVEIRA, 2007, p.171)

Pensar o mapa como uma linguagem que consegue ultrapassar a leitura técnica também é uma forma de dar vida ao mesmo. Petchenik (1995) faz menção a comunicação como resultado de uma relação entre interlocutor e o receptor. Assim o leitor também se torna autor, não ficando de fora do processo de confecção, já que o mesmo teria sido elaborado justamente para conseguir alcançá-lo. Como afirma Carlos (2001),

O mundo se cria e se recria a partir das relações que o homem mantém com a natureza e da maneira como ele se constrói como sujeito. Nesse processo ele não só constrói o mundo, mas também um modo de entendê-lo e explicitá- 
lo enquanto possibilidade aberta de transformação (CARLOS, 2001, p. 28).

Sendo o leitor um participante ativo do processo de transformação e confecção da realidade em que está inserido, pensar o mapa como sua representação é enriquecedor e transformador sob a égide da autonomia.

Sendo assim, o mapa em sala de aula estabeleceria raciocínios geográficos, buscando entendimentos ligados a espacialidade produzida pelas sociedades. Para que isso ocorra é necessário que os conceitos básicos sejam trabalhados assim como as ideologias contidas em cada representação sejam desveladas e problematizadas, para que a leitura do mapa não fique limitada apenas aos contornos dos mapas políticos, ou a localização dos rios em mapas físicos, como se observa na maioria das vezes. Por isso faz-se necessária a alfabetização cartográfica, pois a mesma,

[...] permite ler e interpretar o espaço próximo ou distante através de símbolos que se relacionam entre si, representando no papel um espaço reduzido, que fornece ao leitor informações que o ajudarão a se localizar no espaço e a compreender os diferentes espaços do mundo e suas dimensões. Esta temática deve ser trabalhada já nas séries iniciais do ensino fundamental, através de jogos e brincadeiras. (MARTINELLI, 1998)

Ler um mapa e conseguir obter informações dele é uma tarefa de grande dificuldade para um cidadão, até mesmo para os professores, se ele não aprendeu a fazer isso na escola. Porém, estas habilidades podem e devem ser desenvolvidas na escola através de exercícios que envolvam conceitos e práticas espaciais no ensino fundamental, que mais tarde facilitarão a análise e leitura do espaço em mapas, nas séries mais adiantadas.

Dessa forma, a responsabilidade do professor de Geografia é muito grande, pois cabe a ele o trabalho inserir os alunos no uso do mapa, possibilitando a sua leitura e interpretação. Para conseguir ler mapas o aluno deve ser alfabetizado, assim como acontece com a escrita e com a matemática.

Alfabetização Cartográfica é uma metodologia que estuda os processos de construção de conhecimentos conceituais e procedimentais que desenvolvam habilidades para que o aluno possa fazer as leituras do mundo por meio das suas representações. É a inteligência espacial e 
estratégica que permite ao sujeito ler o espaço e pensar a sua geografia. (PASSINI, 2012,p.13)

A definição acima é capaz de evidenciar a grande importância da alfabetização cartográfica na vida do sujeito, reforçando o seu papel na compreensão do mundo, bem como as colaborações que se darão a partir desta compreensão.

Franscischett (2004) afirma que o ensino de Cartografia está calcado no aprendizado de conceitos chaves e que considera básico: representação espacial-globo e mapas políticos e físicos, cartas topográficas, plantas, fotografias áreas, imagens de satélite; escalas gráficas e numéricas; simbologia: convenções cartográficas, linhas imaginárias, legenda, paralelos, meridianos, cotas e coordenadas geográficas. Segundo a autora, compreender estes conceitos faz com que se inicie o início do desenvolvimento sistemático para compreender a cartografia.

Diante desta realidade é necessário que o professor também incentive que seus alunos produzam mapas e instrumentos cartográficos que representem a realidade em que eles estão inseridos, pois se assim não for, estaremos, como professores, limitando as possibilidades de representação de cada um segundo a realidade em que estão inseridos, deixando-os engessados dentro de um padrão, e é sabido que o ensino de Geografia deve possibilitar a libertação, formando cidadãos críticos que possam refletir as várias manifestações de aprendizado.

Almeida (1999) ainda afirma que a observação da realidade e do espaço próximo da criança, favorece o trabalho de localização e representação dela, podendo, desta forma, desenvolver sua própria realidade, ou seja, sua espacialidade em um desenho.

Para interpretar um mapa é necessário ir além do que está sendo representado. É preciso ter um conhecimento dos porquês das representações. Por isso,

[...] que apenas a alfabetização cartográfica, concebida como "aprendizagem do alfabeto cartográfico", não propicia que alunos e professores leiam mapas. Para que tal fato ocorra é preciso que seus usuários, além de terem domínio dessa linguagem, saibam os conceitos e informações relacionados aos temas representados nos 
mapas. Caso contrário, a leitura dessa representação inviabiliza-se. (SOUZA e KATUTA, 2001, p.116)

Assim, é importante ressaltar que estas dificuldades estão, muitas vezes, ligadas à a construção de conhecimentos pelos estudantes, sendo importante que se busque uma linguagem que facilite o entendimento do aluno, pois nem sempre os mesmos compreendem os conceitos espaciais utilizados na linguagem do professor, tendo o mesmo, a função de rever estes conceitos e também a maneira de desenvolvê-los no processo de ensino-aprendizagem.

Dessa maneira é possível salientar, que os autores aqui apresentados vão traçando um caminho que revela a importância que a linguagem cartográfica tem no processo de leitura do mundo, bem como na emancipação dos sujeitos. Por isso ela, deve ser desenvolvida e entendida como linguagem essencial na Geografia.

A cartografia escolar ocupa então, um lugar de grande valor no processo de conhecimento geográfico, não podendo estar fora da escola, portanto, deve ser estudada e entendida como linguagem essencial na aprendizagem.

Do ponto de vista do raciocínio geográfico, a cartografia escolar é essencial, pois contribui no entendimento da realidade, destacando a localização, distribuição e correlação dos fenômenos, inclusive possibilitando a articulação de diferentes escalas espaço-temporais. A cartografia contribui no aprofundamento da pergunta que norteia o raciocínio geográfico: por que as coisas estão onde estão?

No próximo capítulo desta dissertação, aprofundaremos o diálogo entre raciocínio geográfico e cartografia escolar. Para tanto, realizamos uma revisão da literatura, reunindo pesquisas que articulam estes dois temas, como o intuito de compreender como elas têm abordado, discutido e problematizado esta relação. 


\section{RACIOCÍNIO GEOGRÁFICO E CARTOGRAFIA: REVISÃO DA LITERATURA}

A relação entre raciocínio geográfico e cartografia escolar tem sido objeto de diversas pesquisas no campo do ensino de Geografia nas últimas décadas. Para que possamos melhor situar esta investigação, fizemos uma breve revisão da literatura com o intuito de compreendermos as abordagens e problemáticas produzidas recentemente neste campo de investigação, bem como identificar possibilidades de diálogo com a nossa pesquisa.

Richter (2017) traz importantes reflexões sobre a construção do mapa e os processos que estão presentes neste campo, buscando desvelar se o mapa é arte ou apenas um desenho, fortalecendo a discussão de que a forma como foi representado não invalida a sua importância, muito menos a sua capacidade de representar um determinado espaço.

Em sua proposta, um dos aspectos que se destaca é a busca em tornar a linguagem cartográfica mais presente na sala de aula, através de caminhos didáticos que permeiem a leitura espacial através de práticas escolares, a fim de permitir que os sujeitos desenvolvam o raciocínio geográfico.

A partir desta análise, é possível perceber que o autor se preocupa com a linguagem cartográfica inserida no contexto escolar e entende que ela pode ser uma grande aliada no processo de ler a sociedade, e auxiliar no desenvolvimento do raciocínio geográfico, contribuindo assim, com a reflexão sobre as diferenças entre pensamento espacial e o raciocínio geográfico, bem como o potencial que há na cartografia escolar, se ela for entendida como linguagem essencial para compreensão do espaço.

Diante disso, para ele, o pensamento espacial é

[...] a compreensão da espacialidade, da localização de determinados lugares no espaço, seu ponto específico, a distribuição dos objetos no espaço, seu lugar. Esta seria uma das primeiras formas de entender a importância de como espaço e o próprio lugar apresentam relevância para o desenvolvimento dos saberes geográficos (RICHTER,2017, p.19)

Sendo assim, esse conceito de pensamento espacial apresentado se relaciona com a capacidade de se localizar no espaço, compreendendo, por 
exemplo, onde está seu bairro, buscando reconhecer melhor os pontos que o ligam as demais áreas da cidade, e assim, possibilitando um maior conhecimento do lugar em que o sujeito está inserido.

O autor apresenta, também, sua definição de raciocínio geográfico, dando mais elementos para caracterizá-lo como essencial na leitura do espaço. Assim, aponta que o raciocínio geográfico,

[...] se caracteriza na possibilidade de compreender como os distintos lugares são formados e construídos, tornando a leitura e a análise espacial mais complexa. Ou seja, é preciso ter como objetivo no ensino de Geografia que o trabalho com os seus conteúdos escolares potencialize o desenvolvimento do raciocínio geográfico. Aqui o mapa novamente entra como uma linguagem pertinente. A linguagem cartográfica no ensino de Geografia pode contribuir neste processo, pois seus diferentes produtos nos permitem articular muito bem as leituras espaciais com os saberes geográficos. (RICHTER,2017, p.19)

Diante disso, o autor deixa evidente que o raciocínio geográfico é uma dimensão mais ampla que o pensamento espacial, ou seja, para o sujeito conseguir raciocinar através dos conhecimentos geográficos, além de desenvolver o pensamento espacial através da localização dos fenômenos, ele terá que compreender as questões sociais, econômicas e políticas que envolvem aquele lugar que está sendo representado através da linguagem cartográfica.

Assim, a cartografia como linguagem essencial, vai possibilitar essa representação espacial, sendo parte integradora deste processo de leitura do espaço. Desse modo, pode-se pensar que será a capacidade de reflexão obtida por meio dos conceitos básicos da Geografia que trará aos sujeitos a possibilidade de desenvolver o seu raciocínio geográfico, apontando as situações que não conseguem ser representadas fisicamente, mas que estão presentes no mapa, fazendo correlações mais aprofundadas do espaço representado e não apenas se localizando nele.

Frente a estas questões apontadas, pode-se perceber que o autor reforça a importância da linguagem cartográfica na sala de aula, bem como as possibilidades de desenvolvimento desta linguagem no cotidiano escolar desde as séries iniciais, reforçando que é importante 
tornar a Cartografia mais presente nas diferentes disciplinas que são ensinadas ao longo da formação inicial, buscando construir uma identidade mais forte da própria Geografia com o desenvolvimento do pensamento espacial e do raciocínio geográfico[...] (RICHTER, 2017, p.22)

Dessa forma traz suas considerações finais, apontando a importância da linguagem cartográfica no processo de desenvolvimento do raciocínio geográfico e pensamento espacial, mencionando-os como essenciais no processo escolar, pois auxiliam na formação da identidade da Geografia, dando aos sujeitos mais elementos para compressão do espaço.

Ascenção et al (2018) aponta a relação existente entre linguagem cartográfica, formação de professores e a criação de práticas pedagógicas na Geografia da sala de aula. A pesquisa apresenta uma discussão sobre o raciocínio geográfico, utilizando-o como facilitador da compreensão de fenômenos, definindo-o como,

[...]um movimento intelectual específico que permite a compreensão das relações de interdependência que esculpem uma dada espacialidade. É, portanto, por meio do Raciocínio Geográfico que são produzidas compreensões referentes à espacialidade de fenômenos. (ASCENÇÃO et al, 2018, p.8)

É, portanto, definido, com base na ideia de que só é possível ser desenvolvido se estiver atrelado a compreensão das categorias de análise da ciência geográfica. Um outro aspecto levantado nesta produção é a análise de como os mapas foram utilizados em práticas pedagógicas de Geografia em algumas escolas da região metropolitana de Belo Horizonte, a fim de perceber como os professores desenvolviam as ações didáticas com a cartografia, e se eles incentivavam o desenvolvimento do raciocínio geográfico dos estudantes.

Diante da leitura do texto foi possível compreender os caminhos pensados para uma prática docente que possibilite o desenvolvimento do raciocínio geográfico com o uso da linguagem cartográfica. Dessa maneira, eles seguiram um percurso didático que ajudou a pensar a questão da formação dos professores, na seguinte ordem:

Duas questões nortearam nossa investigação: Qual a demanda colocada para os alunos quando da utilização de mapas? O que revela essa demanda sobre a compreensão dos mapas para a 
interpretação geográfica? Os professores contemplados nesta análise utilizaram, sobretudo, mapas disponibilizados em livros didáticos. As atividades solicitadas pelos professores gravitaram em torno de quatro ações: (i) identificar o que estava representado, (ii) localizar e (iii) descrever a distribuição e (iv) calcular distâncias a partir dos mapas. Nem todos os professores desenvolveram todas essas ações, mas não nos ateremos à quantidade de ações desenvolvidas, mas ao que elas nos permitiram inferir em relação à interpretação da espacialidade. (ASCENÇÃO et al, 2018, p.11)

Dessa forma, seguindo essas sequências de questões, foram realizadas atividades a fim de perceber a relação que esses professores tinham com a linguagem cartográfica, a fim de compreender as possibilidades que elas trariam para o desenvolvimento do raciocínio geográfico e compreensão do espaço dentro da sala de aula, como prática docente capaz de promover um pensamento crítico. Diante destas sequências de questões, percebeu-se então que

Não ensinamos os futuros professores a buscar a compreensão
das espacialidades através dos mapas, ou a produção de mapas
que expressem espacialidades interpretadas. Também não
ensinamos a esses sujeitos a construção de interpretações
geográficas, mas sim a leitura isolada de componentes espaciais
e dos processos que sobre eles atuam. (ASCENÇÃO et al, 2018,
p.18)

As discussões apontaram para a formação inicial do professor, trazendo uma reflexão sobre o formato das licenciaturas que são oferecidas nos cursos de Geografia, sendo que muitas delas têm um perfil de bacharelado, não sendo explorado o potente discurso dos conceitos e temas da Geografia para fins didáticos ou que promovam o desenvolvimento do raciocínio geográfico. Sendo assim, aponta a necessidade de pensar as estruturas destes cursos, a fim de buscar melhorias, pois

Inferimos que a formação inicial, através da fragmentação dos conhecimentos, reforça o estudo dos conceitos e procedimentos cartográficos como conteúdo estanque em um curso de licenciatura em Geografia, distorcendo a compreensão das representações cartográficas como linguagem para a expressão da interpretação das espacialidades. (ASCENÇÃO et al, 2018, p.16) 
Dessa forma, é possível compreender que as discussões são focadas na formação docente e como essa formação pode ou não contribuir com o desenvolvimento de práticas capazes de colaborar com o pensamento crítico, formado através do raciocínio geográfico, que para os autores "constitui então o modus operandi do intelecto fundamental para a compreensão da espacialidade do fenômeno e da decodificação das Práticas Espaciais" (Ascenção et al, 2018,p.9), ou seja se desenvolve a partir de conceitos que a Geografia vai oferecer tanto na formação docente, quanto no que é levado para o contexto escolar como conteúdo, pensado através de instrumentos curriculares. Assim, apontam que o raciocínio geográfico pode ser desenvolvido de forma ampliada se começar na formação docente, sendo uma possibilidade de pensar as práticas que serão mais tarde exercidas na sala de aula.

Em outra pesquisa analisada, Costa et al (2012), traz importante debate sobre do uso da linguagem cartográfica nas aulas de Geografia. Através do levantamento bibliográfico, os autores buscaram compreender a importância e eficácia da linguagem cartográfica pois,

Como toda linguagem, cartografia e sociedade estão integradas de modo inseparável. Ela é um conhecimento desenvolvido desde a Pré-história. O homem, ao explorar o espaço a sua volta, procurou representá-lo para os mais diferentes fins. (COSTA, 2012, p.5)

Sendo assim, essa linguagem estando presente no cotidiano escolar, pode colaborar de maneira positiva com o desenvolvimento da análise do espaço pelo aluno. Assim, os autores fazem uma análise através da observação de alguns documentos curriculares, refletindo a partir do que alguns autores apontam como caminhos para que a linguagem cartográfica se efetive no ambiente escolar.

A maneira como a linguagem cartográfica se destaca no contexto da sala de aula é por meio do mapa e, segundo Costa et al (2012, p.7) o mapa é, "notadamente, um dos produtos cartográficos mais utilizados nas aulas de Geografia", por meio da sua presença nos livros didáticos, um dos instrumentos que chegam como mais facilidades nas mãos dos estudantes. 
[...]constitui um importante instrumento metodológico à disposição do professor de Geografia. Ela deve estar presente na análise geográfica, com o intuito de proporcionar práticas e reflexões que levem o aluno à compreensão do espaço no qual está inserido e que nele possa se localizar e agir. (COSTA et al, 2012, p.10)

Assim, fortalece-se a ideia de que ela é importante, e não deve estar fora do processo de aprendizagem, pois possibilita uma análise do lugar, fornecendo elementos importantes para a compreensão da realidade representada, sendo essencial então no desenvolvimento do raciocínio geográfico.

Jaques et al (2016) apresenta os resultados de uma oficina realizada com estudantes do sexto período do curso de Pedagogia da Universidade Federal do Espírito Santo (UFES). O público-alvo é justamente profissionais que vão trabalhar com alunos dos anos iniciais do ensino fundamental, pois segundo os autores, "esses profissionais precisam ministrar aulas sobre assuntos que não estão preparados" (2016, p.1 ). Dessa forma, as oficinas colaboraram com as aprendizagens favorecendo o desenvolvimento do raciocínio geográfico, trabalhando os conceitos teórico-metodológicos da cartografia escolar.

Em um primeiro momento, realizado no dia 31/03/2016, pedimos às alunas que fizessem um mapa do trajeto, a partir de suas experiências diárias. A tarefa proposta foi à seguinte: Elabore um mapa tendo como representação espacial o caminho da sala de aula no Centro de Educação (UFES-Vitória), prédio IC IV, sendo este o ponto de partida, até o Refeitório Universitário. (JAQUES et al, 2016, p.10)

A aplicação desta atividade tinha o objetivo de identificar as noções básicas de cartografia, e assim o autor pode constatar algumas questões, e em seguida, fazer algumas observações pertinentes sobre elas:

A análise deste primeiro trabalho permitiu apurar as principais dificuldades encontradas pelas alunas em relação aos conceitos básicos de Cartografia. [...] Os mapas elaborados não traziam informações básicas para que outras pessoas pudessem interpretá-los. Por exemplo, os mapas não apresentavam pontos de saída e de chegada. Isto é, os pontos referenciais eram aqueles que as alunas consideravam importantes, sem conexão com outras informações básicas (conjunto de elementos espaciais que caracterizam uma dada porção espacial, reconhecido por aqueles que transitam no local). Essa deficiência se agravava pela ausência de título e legenda; fato 
justificado pelas alunas devido ao seu conhecimento do lugar. Também, elaboraram "mapas ao redor de seus próprios umbigos" (como constatou uma Aluna) e somente elas poderiam fazer a leitura correta dos mapas. (JAQUES et al, 2016,p.11)

Partindo desta análise, o autor reforça a importância das noções básicas da cartografia, como localização e pontos de referência, para orientar na produção dos mapas, destacando também que faltam alguns elementos essenciais na leitura deste "mapa" (título e legenda) prejudicando a sua interpretação.

Assim, vale ressaltar que a formação inicial precisa reforçar essas questões primordiais que tangem a alfabetização cartográfica, pois, sem elas, a compreensão e interpretação dos mapas não acontece de maneira a produzir um raciocínio geográfico, pois o mesmo não consegue informar, muito menos representar de maneira evidente o espaço.

Após levantar essas questões, em um outro encontro, os alunos realizaram uma aula expositiva a fim de contribuir com a melhora das noções básicas de cartografia. Após isso, realizaram uma segunda atividade:

Pedimos que elas se dividissem em três grupos para que elaborassem uma maquete. A tarefa proposta foi realizada com base na seguinte pergunta: Construir uma maquete utilizando se de uma base de isopor e representando os objetos espaciais através de materiais recicláveis, tendo os temas propostos, praia, meio rural, cidade, manifestação cultural e ecossistema manguezal. Com as fotografias impressas das maquetes, pedimos novamente que os grupos produzissem um mapa, com base naquilo que elas estavam observando. (JAQUES et al, 2016, p.12)

Diante desta atividade é possível perceber a importância das representações espaciais, e como elas podem auxiliar na compreensão dos fenômenos que se dão no cotidiano. A busca por uma formação docente que vise essas questões precisa estar presente no debate do desenvolvimento do raciocínio geográfico. Por isso o autor, vai traçando estratégias para suprimir as dificuldades que encontra no percurso.

Assim, após a aplicação deste bloco de atividades, foi possível perceber alguns avanços: 
Nestes mapas, produzidos pós-contato com aulas de conhecimentos específicos, constatamos um grande avanço no estágio de desenvolvimento, pois percebemos que as alunas elaboram mapas através de algumas convenções cartográficas, isto é, colocando títulos apropriados, utilizando escalas adequadas e mostrando o plano de visão correto, como o plano vertical e não o obliquo como faziam anteriormente. A evolução das alunas com a inclusão de aulas de conhecimento específico de Geografia tende promover uma mudança radical para melhorar os sentimentos de segurança ao trabalharem essa matéria. .(JAQUES et al, 2016,p.14)

Sendo assim, é possível perceber que o artigo aponta a cartografia escolar e todas as nuances que a envolvem, focando bastante na alfabetização cartográfica, e seus efeitos no desenvolvimento dos sujeitos. Através das atividades práticas citadas, as oficinas foram dando aos professores condições de pensar a Geografia que iriam produzir em seus núcleos escolares, fazendo com que eles praticassem antes de ir para suas respectivas salas, tirando suas dúvidas, aprendendo com base nos seus erros e traçando, assim, um perfil mais seguro para suas práticas em sala de aula. Assim, o artigo aponta alguns caminhos que podem ser percorridos para que as práticas nos anos iniciais do Ensino Fundamental, sejam capazes de promover essa inclusão deles nos conhecimentos geográficos, através da cartografia.

A formação de professores é o foco central, fornecendo assim uma maior compreensão das potencialidades da cartografia no momento de grande importância de apropriação destes conhecimentos, que é a fase inicial dos estudos da criança, pois fornecerá a eles os elementos básicos para se apropriarem da Geografia, e ir então, de maneira primária, ampliando o raciocínio geográfico na escola.

Em artigo publicado em 2012, Seemann discute a necessidade de se repensar a cartografia escolar. Dessa maneira o termo subverter ganha centralidade na discussão proposta, buscando trazer para a sala de aula uma cartografia que seja crítica, que ajude os sujeitos a se formarem como "cidadãos". Neste contexto, Seeman (2012, p.3), aponta que, "subverter a cartografia, significa questionar e desafiar a visão (pre)dominante (e às vezes excludente) sobre o fazer cartografia e procurar formas alternativas de representar espaços, lugares e territórios." 
Todo esse processo de subversão da Cartografia brasileira proposta pelo autor acontece na sala de aula, a partir da leitura de textos que promovem reflexões e também da análise de mapas presentes em livros didáticos, e exercícios envolvendo mapas mentais, e também algumas imagens retiradas da internet, reforçando assim a importância desta linguagem no contexto escolar de maneira crítica, promovendo uma leitura do lugar.

Diante disto é possível pensar então que a linguagem cartográfica é extremamente importante, pois

[...] é uma ferramenta poderosa para democratizar o acesso a mapas e estimular mapeamentos, sob a premissa de que a educação cartográfica não deve ser um ensino de cima para baixo, mas uma prática social integrada nas nossas vidas. (SEEMAN, 2012, p.29 e 30)

Assim, ele apresenta uma cartografia que é capaz de se reinventar, possibilitando aos sujeitos um olhar único para representação do lugar em que vivem. Uma das atividades apresentadas mostrava a representação do mapa mundi por crianças e adolescentes do Ceará, através de um concurso de mapas.

Nesta atividade foi possível perceber a visão que cada um tinha do mundo, bem como as formas que encontraram para representá-lo. Sendo assim, o autor busca incentivar a produção cartográfica sob um viés que valoriza os sujeitos e suas percepções da realidade em que estão inseridos, bem como a capacidade de enxergar nelas aspecto globais, dos quais eles fazem parte. Para Seeman (2012, p.29) "a cartografia subversiva, aponta representações cartográficas de uma maneira mais lúdica, talvez irônica, mas não menos séria".

Assim ela vai além do que é posto pela cartografia oficial, que,

Geralmente, é considerada como uma ciência exata baseada em fatos objetivos, cálculos, medições e convenções (Harley, 1989). A produção de mapas se realiza de acordo com essas regras que definem procedimentos, métodos e práticas. (SEEMAN, 2012, p.3)

Sendo assim, ele vai fazendo uma crítica a essa cartografia oficial, mas não a exclui, reforçando a importância de compreendê-la, para assim subvertêla. Por isso é, bastante importante conhecer os métodos e estratégias que a 
cartografia oficial aponta, pois só assim existirão argumentos para pensar a sua subversão. Dessa forma, ela pode contribuir bastante no momento de pensar a linguagem cartográfica como um caminho para representar o lugar e os seus desdobramentos da vida dos sujeitos.

Por isso, a cartografia oficia, talvez não seja capaz de dar conta de representar situações vividas no lugar, mas recriar essa cartografia, baseado no conhecimento que se tem dela. Segundo o autor, traz possibilidades que auxiliam muito na compreensão da representação do espaço vivido, pois,

Ler e fazer mapas - oficiais ou subversivos, imaginários ou reais, materiais ou digitais, do bairro ou do mundo inteiro - são atividades imprescindíveis para transformar a educação cartográfica em um projeto pluralista. (SEEMAN, 2012, p.30)

Por isso, é importante reforçar que a linguagem cartográfica tem potencial transformador e a medida em que for pensada a fim de promover o raciocínio geográfico, vai ganhar mais sentido no contexto escolar, e será de constante aprimoramento nas práticas docentes.

De modo geral, os artigos aqui apresentados trazem reflexões importantes e que foram de grande valia para pensar as contribuições da cartografia escolar no desenvolvimento do raciocínio geográfico. As experiências registradas, bem como as leituras realizadas apontam para a importância que existe no uso e compreensão da linguagem cartográfica no cotidiano escolar, pois ela é capaz de possibilitar a leitura do mundo através do mapa e, consequentemente, a leitura do lugar. A compreensão das escalas de acontecimento dos fenômenos fica expressas nessa linguagem, assim ela pode ser utilizada de maneira a promover a emancipação dos sujeitos.

No entanto, após as leituras, foi possível apontar algumas lacunas, que podem ser preenchidas, se pensarmos de maneira mais ampla e prática, a questão do desenvolvimento do raciocínio geográfico. Após a análise, foi possível pensar que uma das dificuldades dos autores está na não construção de conceitualização do raciocínio geográfico, dificultando a avaliação do seu desenvolvimento. Assim, se não existe uma concepção do que ele é, suas características e suas formas de expressão, dificilmente será possível analisar o seu desenvolvimento na sala de aula. 
Dessa forma, foi possível compreender que nenhum dos artigos apontou um caminho para analisar se os sujeitos estavam ou não desenvolvendo seu raciocínio geográfico ao longo do processo. É possível pensar que a não conceitualização do que seja o raciocínio acaba por dificultar ações que ajudem a pensá-lo, e até mesmo perceber o seu desenvolvimento na vida dos sujeitos.

A pesquisa aqui proposta é, então, uma tentativa de analisar esse desenvolvimento do raciocínio geográfico, a partir de sua conceitualização (feita no capítulo anterior), buscando, através de situações de aprendizagens que foram se desenrolando, ao longo de um ano letivo, percebendo seus conhecimentos prévios, sua capacidade de articular os conceitos aprendidos, bem como as dificuldades apresentadas para chegar a esse desenvolvimento.

Essas situações de aprendizagem foram aplicadas sempre na tentativa de incentivar o sujeito a buscar respostas para alguns problemas, utilizando seus conhecimentos geográficos, através da leitura de mapas e imagens.

É importante ressaltar que, como dissemos, os estudantes já chegam na escola com diferentes raciocínios geográficos e o papel da escola é ajudá-los na construção e aprimoramento de raciocínios geográficos cada vez mais complexos. Por isso, as sequências produzidas visam levantar os raciocínios prévios dos estudantes para que, ao final do processo, possa ser avaliado se as mediações didáticas propostas contribuíram na elaboração de raciocínios geográficos mais complexos.

Quando nos referimos a raciocínio geográficos mais complexos aludimos a capacidade dos estudantes de produzir leituras da realidade, ressaltando a localização, distribuição e correlação espacial dos fenômenos, articulando diferentes escalas e utilizando conceitos próprios da geografa, como lugar, território, espaço, entre outros, na elaboração de seus argumentos.

Assim, as situações de aprendizagem a seguir, tem o objetivo de perceber como o desenvolvimento do raciocínio geográfico ocorre com as contribuições da cartografia escolar, e quais percursos podem ser realizados para atingir esse objetivo, que é o de ajudar o sujeito a ler o mundo através da Geografia ampliando seus conhecimentos. 


\section{ESTUDO DE CASO}

Esta pesquisa foi realizada em minhas aulas de Geografia no período de abril a outubro de 2019, na Escola Estadual José Chediak, com aproximadamente 110 alunos que compõem o sexto ano do Ensino Fundamental II.

A escola está situada no Parque São Lucas, subprefeitura da Vila Prudente, Zona Sudeste, na periferia da Cidade de São Paulo. Segundo informações de moradores, o bairro surgiu em 1944. Nessa época, a região era apenas um grande brejo, a leste da capital. Essas terras pertenciam aos irmãos Antônio, Luís e Domingo de Luccas, cujo sobrenome deu origem ao nome do futuro bairro.

Outro sujeito importante na criação deste bairro foi Francisco Fett, um imigrante alemão chegado ao Brasil logo após o término da Primeira Guerra Mundial. Com o capital da venda de uma cervejaria que possuía em Munique, comprou uma gleba de terras, com estradas de terra e muitas inundações, conhecido até então como Parque Santa Maria. O bairro se consolidou, com o passar do tempo, com o surgimento de forte comércio e novas moradias.

Atualmente é um bairro que mescla residências, com forte comércio no seu entorno. O parque São Lucas é caracterizado como um local de comércio para outros bairros do entorno e da periferia, ficando como uma espécie de centro comercial da região. 

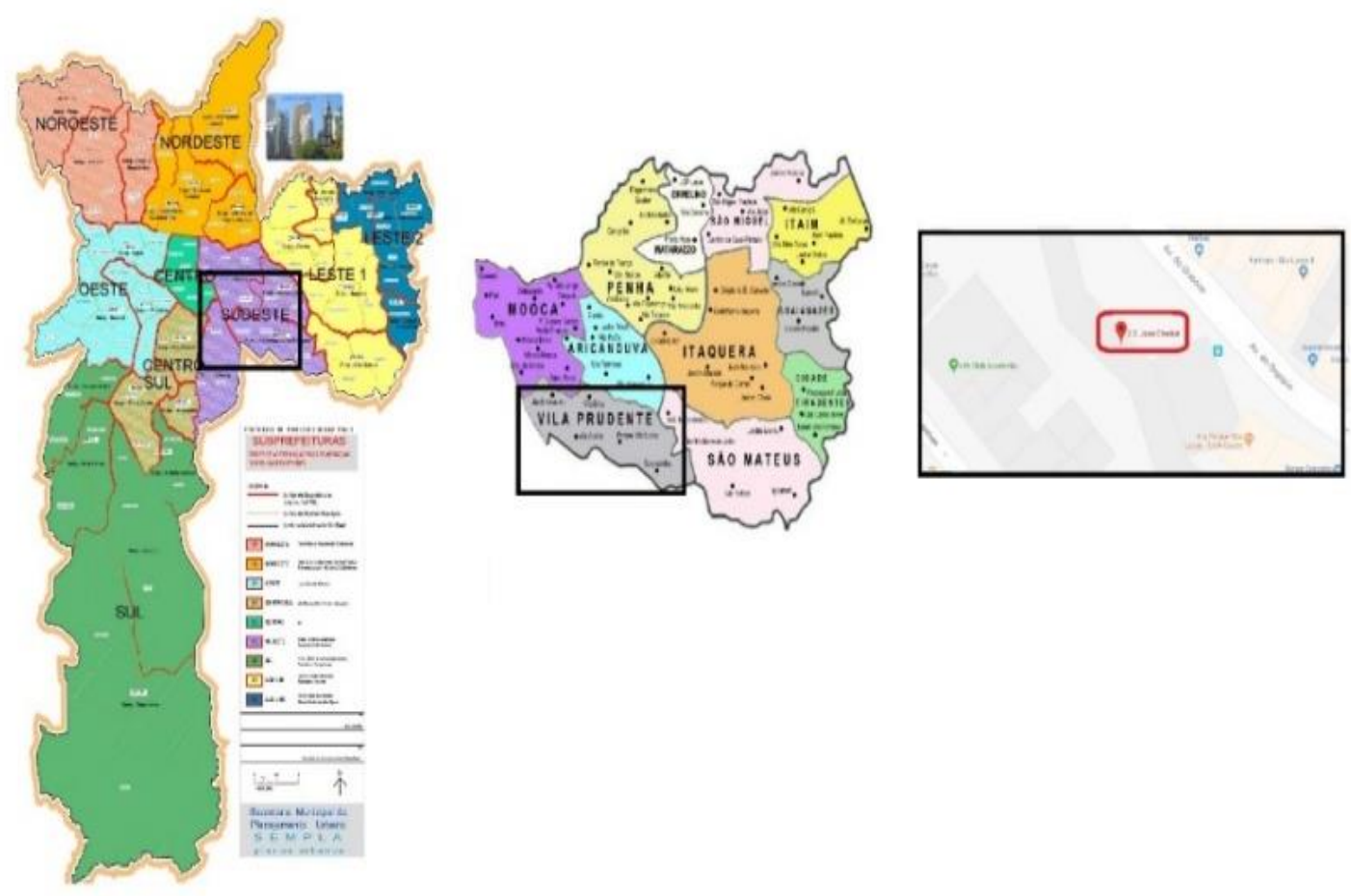

Fonte: Secretaria municipal do planejamento urbano de São Paulo.

É neste bairro que está localizada a Escola Estadual José Chediak, onde atuo como professor da rede Estadual desde o ano de 2014. A escola conta, desde 2005, com o trabalho da diretora efetiva Vilma Lanzotti, que assumiu a mesma, fazendo com que a escola passasse por mudanças na qualidade do ensino e estrutura física. Segundo relatos da diretora "quando ela assumiu essa escola, a mesma era repleta de pichações e sobravam vagas nas turmas". Depois de um trabalho intenso junto à comunidade e grupo de professores a escola foi se transformando.

O segredo para reverter o antigo cenário, segundo a diretora, foi "chamar os pais para discutir com professores e alunos o que seria necessário para melhorar a qualidade de ensino". No mínimo quatro vezes ao ano são realizadas reuniões. Nelas, é possível contar com a presença de $70 \%$ dos pais, o que fortalece o diálogo entre escola e família.

Dessa forma, atualmente a Escola Estadual José Chediak é procurada não apenas por alunos que moram no Bairro Parque São Lucas. Alunos das 
imediações e até de cidades da região metropolitana buscam a escola, fazendo com que ela tenha até mesmo uma lista de espera por vagas.

A escola tem um grupo de professores em sua maioria efetivos e funciona nos três turnos, atendendo duas etapas de ensino (Ensino Fundamental II, Ensino Médio) e uma modalidade (Educação de Jovens e Adultos).

Desde que iniciei à docência em 2014, o público alvo das aulas são majoritariamente o Ensino Fundamental II, em especial, as turmas de sexto ano.

As inquietações do cotidiano escolar, somados ao desejo de conhecer mais sobre os caminhos da cartografia e sua contribuição para o desenvolvimento de um pensamento crítico, foram as bases fundantes para o início desta pesquisa. Entender o lugar, e perceber suas influências na escola, também foram importantes no momento de escolher o que e como pesquisar.

Dessa forma, em busca de uma educação geográfica significativa, buscando entender que os sujeitos precisam encontrar sentido naquilo que estão aprendendo, faz-se necessário então, uma geografia que colabore com a leitura do mundo.

Como o homem percebe o mundo? É através de seu corpo de seus sentidos que ele constrói e se apropria do espaço e do mundo. O lugar é a porção do espaço apropriável para a vida apropriada através do corpo - dos sentidos - dos passos de seus moradores, é o bairro é a praça, é a rua. (CARLOS, 2007, p.17)

A leitura do mundo é, antes de tudo, a leitura do lugar, e isto implica em conhecer o local onde vive, suas características, bem como suas contradições e articulações com outras escalas espaço-temporais. A Cartografia é uma grande aliada na hora de representar esse espaço e suas realidades. Desta forma, ela contribui para que o sujeito busque entender a localização dos fenômenos, e não somente percebê-los. O raciocínio geográfico vai possibilitar então, que essas representações ultrapassem o limite da ilustração, construindo correções entre fenômenos, processos, agentes e escalas. Através de correlações, o aluno conseguirá compreender os vários processos que envolvem o fenômeno, possibilitando conexões com os conteúdos aprendidos, dando ao mapa(representação) um sentido mais amplo. 
A necessidade de compreender os processos que envolvem 0 desenvolvimento do raciocínio geográfico, e suas potencialidades, foi o que colaborou para que esta pesquisa se realizasse na sala de aula onde atuo, pois acredito que assim, seja possível estabelecer relações concretas com o que está sendo trabalhado cotidianamente na escola e o desenvolvimento dos alunos, mediante as situações problemas.

Em busca de colaborar com esse desenvolvimento, a partir dos conteúdos trabalhados, e refletidos, foram pensadas situações de aprendizagens, através das quais os estudantes pudessem refletir sobre a própria realidade, buscando então encontrar possíveis soluções para os problemas encontrados em cenas cotidianas de suas vidas em diálogo com outros lugares e realidades. Dessa maneira,

A aplicação de conceitos na resolução de situações-problema, consiste em criar situações de desafio, cuja solução não está contemplada nas respostas nos livros(...) não é uma tarefa cuja respostas é simples e disponível, mas é a vivências de uma investigação, por meio da vivência de um método científico. (PASSINI,2012, p.202)

Assim, partimos do pressuposto de os alunos começarão a articular o conhecimento que tem dos temas, em busca de possíveis soluções, e desenvolverão suas habilidades geográficas de maneira criativa. Como isso, poderão construir interpretações da realidade com foco na dimensão espacial, correlacionado fenômenos e articulando diferentes escalas espaço-temporais, o que chamaremos ao longo deste estudo, de raciocínio geográfico.

Para entender as maneiras como o raciocínio geográfico é desenvolvido, foi pensado um conjunto de atividades para serem realizadas pelos alunos, e depois analisadas para entender a fragilidades e potencialidades no processo de aprendizagem em geografia. As atividades propostas têm níveis de dificuldade diferentes e visam desenvolver aspectos relacionados a maneira de pensar 0 lugar, suas representações e desafios.

As primeiras atividades são relacionadas a conteúdos especificamente cartográficos como orientação e identificação de elementos que compõem um mapa e tem o objetivo de fortalecer nos alunos os conhecimentos básicos e 
essenciais para que um sujeito seja considerado alfabetizado cartograficamente. Como discutido no capítulo anterior, partimos da premissa de que,

(...) a alfabetização cartográfica, é um processo que pressupõe, a aquisição e o desenvolvimento dos conceitos de: visão vertical e visão obliqua. Imagem bidimensional e imagem tridimensional. Alfabeto cartográfico: ponto, linha e área. Proporção e escala. Lateralidade, ponto de referência e orientação. (SIMIELLI,200, p.107)

Sendo assim, cada atividade realizada tem foco no desenvolvimento de cada uma dessas habilidades essenciais para a leitura do mapa e na capacidade dos sujeitos de relacionar as problemáticas com os conteúdos em busca de soluções que desenvolvam o raciocínio geográfico.

Para colaborar com a compreensão e facilitar o entendimento dos conceitos e temas desenvolvidos nas situações de aprendizagem, foram elaborados alguns mapas conceituais, na tentativa de explicitar o tema, bem como os objetivos que pretendia-se alcançar em cada uma das sequências.

Os mapas conceituais são amplamente utilizados em todo o mundo por pessoas de todas as idades para expressar a sua compreensão sobre diversos domínios do conhecimento (CAÑAS, NOVAK e REISKA,2015). Dessa forma pode-se entender que os mapas conceituais são ferramentas importantes e que ajudam a aumentar a visibilidade das ideias complexas, facilitando a discussão sobre um determinado tema estudado.

Assim, eles se fazem presentes nesse estudo para fortalecer a compreensão das situações desenvolvidas com os sujeitos, colaborando com uma maior compreensão de seus objetivos, e facilitando a observação dos conceitos desenvolvidos. 


\subsection{SITUAÇÃO DE APRENDIZAGEM 1 - Orientação Geográfica}

MAPA CONCEITUAL: SITUAÇÃO DE APRENDIZAGEM 1- ORIENTAÇÃO

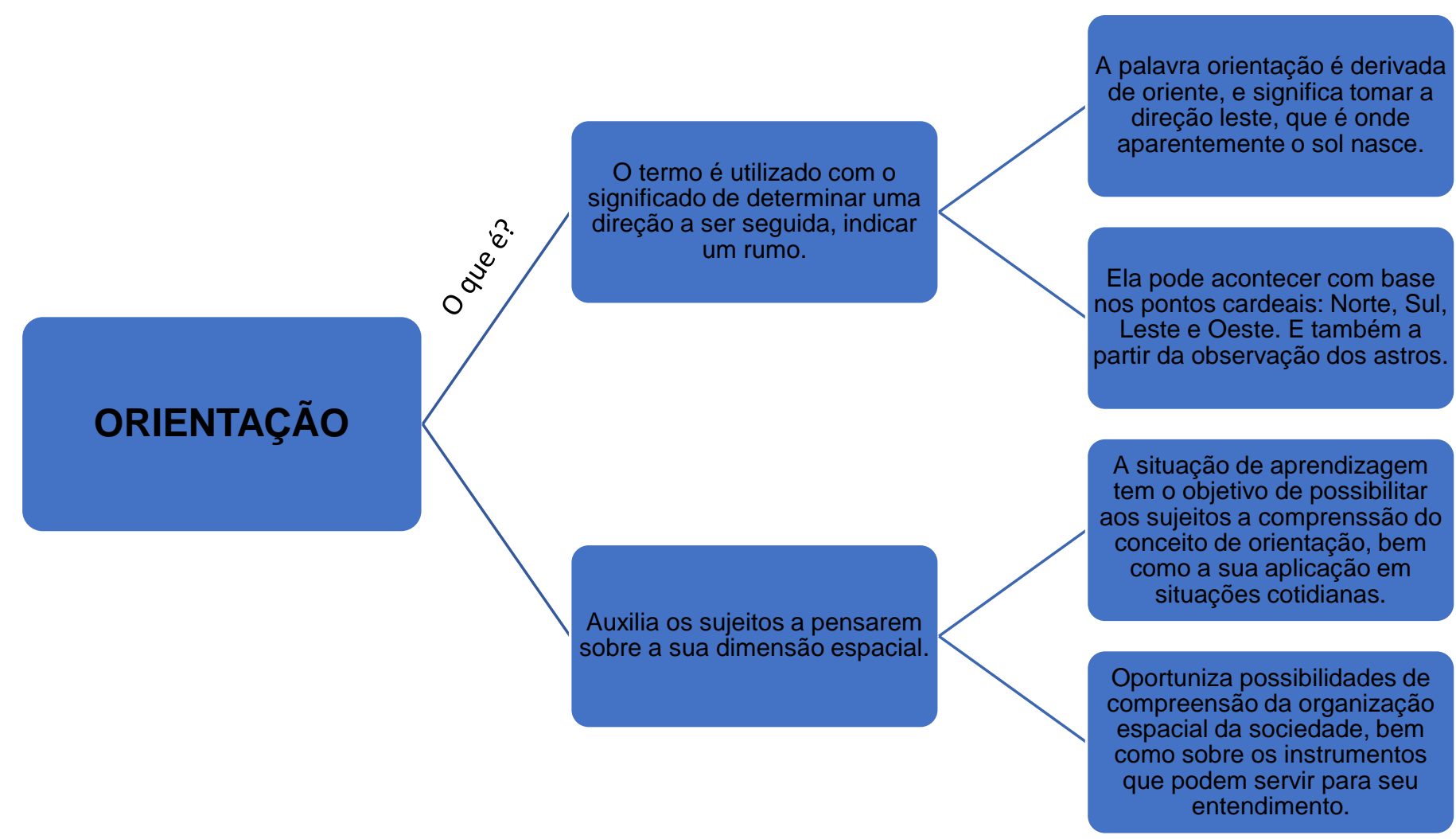

O primeiro conteúdo que foi pensado para a realização desta atividade tem relação com a orientação. Entender o conceito de orientação, e mais do que isso, saber se orientar no espaço é um dos conteúdos da Geografia que possibilita aos sujeitos pensarem sobre sua dimensão espacial e do lugar em que vivem.

É importante ressaltar que, antes de serem criados os conceitos técnicos de orientação no espaço, os sujeitos já criavam suas próprias estratégias para isso, reforçando então, o que já foi debatido neste texto, que o conhecimento da Geografia é inerente aos sujeitos sociais. Eles fazem e seguem fazendo uso desse conhecimento para sobrevivência e permanência no mundo. 
Abordar essa temática na sala de aula parte da ideia de que compreensão deste tema oportuniza possibilidades de compreensão da organização espacial da sociedade, bem como sobre os instrumentos que podem servir para seu entendimento. Dessa maneira, através dos conceitos de orientação, realizamos a situação de aprendizagem.

$\mathrm{Na}$ elaboração da situação, foi possível observar que alguns livros didáticos trazem o conceito de orientação sempre relacionado com a orientação pelo sol, sendo que os pontos cardeais são aprendidos com a figura de um menino com os braços abertos e com o braço direito apontado para o Leste. Essa forma de orientar pode causar alguns equívocos, dentre eles, o de que 0 Leste está sempre do lado direito.

Para tentar superar essa situação, é importante que os pontos cardeais sejam trabalhados com o globo terrestre, pois é uma representação mais próxima do que seria a real forma da Terra e sua posição no sistema solar.

Sendo assim, o conceito de Leste ao lado direito vai perdendo sentido, e o sujeito constrói o conceito de maneira correta, sem fazer correlações de embaixo ou em cima, entendendo que a orientação é sempre feita em relação a algo, e não é um conceito fixo em todos os momentos.

O objetivo da atividade abaixo é justamente o de perceber se em uma situação adversa, perdido em uma floresta, é possível se orientar e buscar uma saída para a essa situação. Abaixo temos a questão proposta aos alunos como ponto de partida da sequência:

"Quatro amigos estão viajando, quando de repente, o carro em que estão, perde o controle, acaba descendo uma ribanceira, e entra em uma floresta. Os quatro amigos, se deram conta depois de um tempo, que estavam realmente perdidos. Nenhum deles tinha um celular carregado, e estavam sem nenhum outro instrumento para se localizar naquele lugar. Qual a estratégia eles podem utilizar para sair da floresta, pedir ajuda, e retornar para casa?" 
Elaboramos um gráfico a partir das respostas dos estudantes. Esse gráfico é apenas um indicativo das possibilidades que eles encontraram para sair da situação proposta na atividade. A partir dessas respostas e da leitura das reflexões é possível traçar um paralelo e perceber se os alunos conseguem utilizar os conhecimentos sobre orientação e pontos cardeais para resolver 0 problema, bem como identificar quais os raciocínios geográficos que os estudantes já possuem.

\section{GRÁFICO 1: Qual a melhor forma de conseguir sair da floresta e encontrar o caminho de volta?}

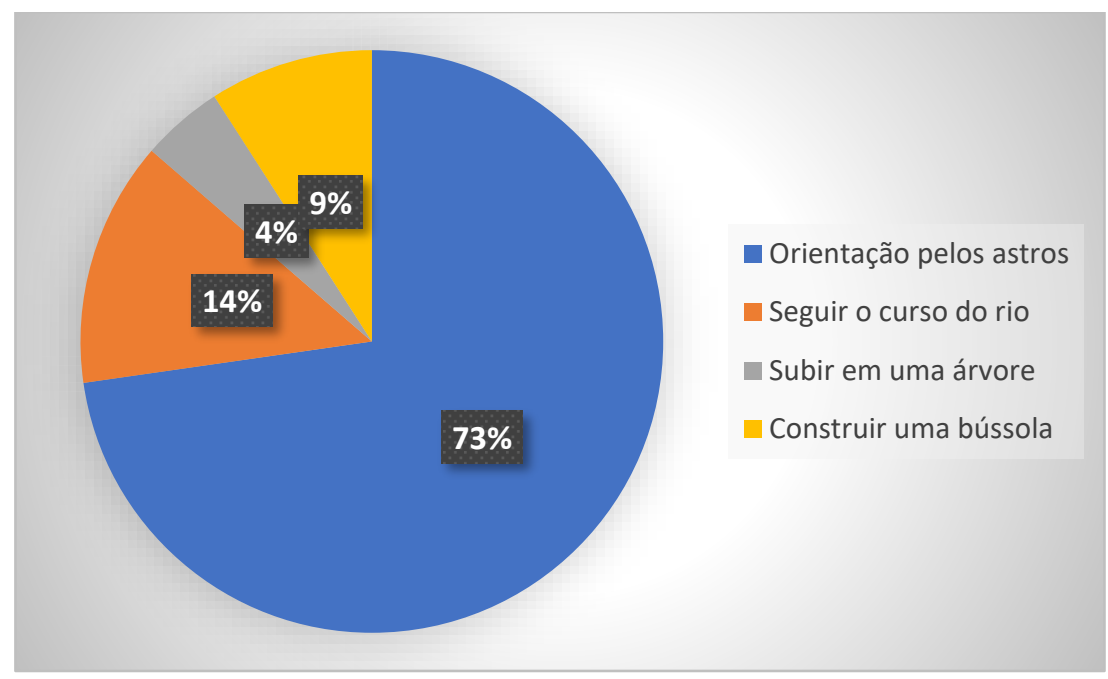

Fonte: elaborado pelo autor, abril de 2019.

Ao observar as respostas dispostas no gráfico, em um primeiro momento o que nos vem à mente, é que a maior parte dos alunos entende que para sair da floresta o caminho mais adequado seria se orientar pelos astros, neste caso, o sol. As respostas davam conta de que a melhor saída seria a de olhar o sol e, a partir dele, orientar-se.

Porém, existe nessa escolha um problema comum, que é o de saber que não é o sol que está se movimentando, mas o planeta. Mesmo com a maioria das respostas neste sentido, foi possível perceber que eles não tinham ainda muita clareza sobre o fato de que as direções Oeste-Leste estão relacionadas 
com o movimento de rotação da Terra. Se eles compreendem que o Sol "surge" a Leste por conta do movimento de rotação, em alguns casos estender o braço direito indicará o Leste.

[...] o leste (nascente) não pode ser ensinado apenas como o "lugar onde o sol nasce" e o Oeste (poente) como "lugar onde o sol se esconde". Na verdade, são os pontos da entrada da Terra na luze/ou na sombra do lugar onde o sujeito se encontra, sendo observáveis pela presença do sol ou pela ausência. (ALMEIDA,2001, p.68)

É importante neste caso voltar a reforçar o movimento aparente do Sol, mostrando que quem se movimenta é a Terra, e por isso não vai ser sempre que o Leste estará na direção do braço direito.

Uma outra parcela sugeriu que uma maneira de conseguir sair da floresta, pedir ajuda e encontrar o caminho de volta seria seguindo o curso do rio. Este apontamento revela que os alunos conseguiram construir alguns conceitos muito importantes na Geografia. Um deles é o de que as civilizações estão sempre se formando próximo de recursos naturais, que são essenciais para o seu desenvolvimento.

Seguir o curso do rio significa que seria possível encontrar a cidade, ou alguma vila, pois desde a primeiras civilizações as populações se aglomeram próximo de leito de rios. Um exemplo que podemos citar, é a sociedade egípcia, que foi denominada como "dádiva do Nilo", exatamente por estar próxima a esse rio, que os abastecia e dava condições para desenvolvimento da agricultura. Além disso, pode indicar que os alunos compreendem a importância de estar próximo do rio para estarem abastecidos de água doce, uma vez que ainda não sabem quanto tempo irão demorar para se localizarem.

Pensar que seguir o rio pode ser uma saída correto é uma maneira de ver que alguns alunos já conseguem assimilar os conhecimentos trabalhados e a junção deles causa esse pensamento, que pode ser visto como uma maneira de raciocinar geograficamente. 
Não está dentro das questões técnicas da cartografia, mas está relacionada ao pensamento de que nenhuma sociedade se desenvolve longe de fontes de água, sendo os rios o recurso fundamental para o desenvolvimento de qualquer cidade. Olhar para ele e segui-lo levaria direto para um lugar onde pessoas estariam aglomeradas, independente do conceito dessa aglomeração.

Outro dado importante obtido nesta primeira atividade são as diversas interpretações que os alunos obtiveram na hora de buscar uma estratégia de sair do local onde estavam "perdidos" para encontrar ajuda. Os alunos tiveram escolhas baseadas naquilo que acreditavam ser o mais coerente e para isso fizeram uso de experiências que obtiveram assistindo filmes, assistindo programas de televisão e até mesmo de experiências realizadas em sala de aula na construção de instrumentos de orientação, como a bússola.

As soluções propostas aqui seguiram até mesmo certas fantasias que alguns criam em torno de situações de sobrevivência em locais inóspitos. Foi também possível perceber que eles desejavam, ao invés de buscar alternativas pra sair da floresta, meios de se instalar nela, se não conseguissem a saída.

Este primeiro momento foi de grande importância para a pesquisa, pois ajudou a compreender que muitas vezes os alunos têm dificuldades de relacionar os conteúdos aprendidos com situações cotidianas, mesmo que criadas em uma situação de aprendizagem da qual eles faziam parte.

Porém, é importante ressaltar que alguns conseguiram compreender 0 objetivo e mesmo encontrando dificuldades conseguiram chegar a uma resposta que segundo eles, seria a ideal para a solução do problema. Dessa forma é importante mencionar que as respostas dos alunos apontam que eles já conseguem apresentar raciocínios geográficos, que são oriundos de suas experiencias cotidianas e, também, com o contato prévio com os conteúdos de geografia nos anos iniciais no ensino fundamental, e ao observarem os conteúdos eles conseguem perceber o sentido daquilo que já vivenciaram, mas agora, enxergando-os como elementos essenciais da Geografia.

É claro que as respostas estão apontando um caminho dentro daquilo que eles aprenderam, e não posso deixar de mencionar aqui que, muitas vezes, por conta da rotina da aula ser extensa, e termos que dar conta de muitas demandas, 
alguns conceitos passam sem serem aprendidos em sua totalidade, reforçando assim a importância de se pensar uma prática que não esteja apenas pautada nas necessidades curriculares lineares, mas naquilo que os alunos também precisam compreender para seguir adiante na construção de novos conhecimentos.

Após aplicação desta situação de aprendizagem 1, foi possível refletir e propor em seguida uma atividade que fosse capaz de problematizar e diminuir as dificuldades que foram encontradas na situação proposta. Isso colaborou para que os alunos conseguissem também enxergar as suas dificuldades frente ao que foi apresentado.

Assim, é importante ressaltar que esta atividade visou aprimorar os raciocínios geográficos já apresentados pelos estudantes, possibilitando que eles desenvolvam raciocínios mais complexos. Fazer o feedback da atividade, possibilitou observar onde eles tiveram mais dificuldades e com 0 desenvolvimento de uma outra atividade ajudá-los a tentar ampliar o que não foi alcançado com a primeira.

Para a realização desta atividade foi utilizado o globo terrestre e seguido as orientações dadas por Passini (2012, p.99), que direciona a atividade da seguinte forma: " tal simulação com o globo terrestre serve para que os alunos consigam imaginar-se movendo-se com a Terra de Oeste para Leste, entrando na claridade pela manhã e saindo dela, ao entardecer".

A atividade foi feita para que os alunos compreendessem melhor a questão da orientação pelos astros, já que na situação de aprendizagem, a maioria mencionou que se orientaria pelo sol para sair da floresta. A questão é que a maioria não conseguia mencionar de que forma e porque seguiriam o sol. Desta forma, a atividade serviu para dar a dimensão do movimento aparente do sol, para que ficasse claro que, nem sempre, o nascer do sol está ao leste.

Para realização, foi feito o seguinte procedimento: escureceu-se a sala de aula para que a claridade presente na sala fosse a iluminação do sol. Foi colocado um sinal com um adesivo representando a nossa posição no globo, e depois girou-se o globo de oeste para leste. Cada vez que a luz alcançava a nossa posição no globo, eles diziam se era noite ou dia, entendendo assim o 
movimento de rotação da Terra. Ao final deste conjunto de aulas sobre o movimento aparente do Sol, foi possível verificar, a partir da participação oral, que os estudantes conseguiam construir argumentos explicando por que iriam se orientar pelo Sol para buscarem uma saída da floresta.

Portanto, essa situação-problema foi importante para iniciar a pesquisa e gerar reflexões sobre o que pode ser feito para melhorar a aprendizagem dos alunos em relação ao conteúdo de orientação. Foi um primeiro exercício que, partindo dos raciocínios geográficos dos estudantes, desenvolveu-se mediações pedagógicas para que os estudantes se apropriassem de conceitos e conteúdo da geografia (como o de rotação e translação) para que pudessem desenvolver raciocínios geográficos mais complexos.

Também é importante destacar que essa atividade aponta para o que precisa ser retomado como conhecimento e de que maneira esse conhecimento pode ser assimilado e ampliado, de maneira que os sujeitos consigam percebêlo nos seus cotidianos. Um dos pontos frágeis desta sequência e que pretendemos aprimorar em nossa prática docente para experiências futuras foi o não-desenvolvimento de um instrumento de avaliação final que pudesse nos possibilitar elementos de comparação entre os raciocínios geográficos dos estudantes antes e pós desenvolvimento da situação de aprendizagem. No momento de aplicação da situação, consideramos que avaliação oral dos argumentos produzidos pelos estudantes seria elementos suficientes para esta análise, o que não se mostrou verdadeiro. Fica, assim, evidenciado a importância da construção de instrumentos de avaliação que façam a mediação e o acompanhamento das aprendizagens dos estudantes para que assim possamos verificar, com maior nível de detalhes, avanços e dificuldades no processo de aprendizagem e de construção de raciocínios geográficos pelos estudantes. 


\subsection{SITUAÇÃO DE APRENDIZAGEM 2- Os Elementos do Mapa}

\section{SITUAÇÃO DE APRENDIZAGEM 2- ELEMENTOS DO MAPA- MAPA CONCEITUAL}

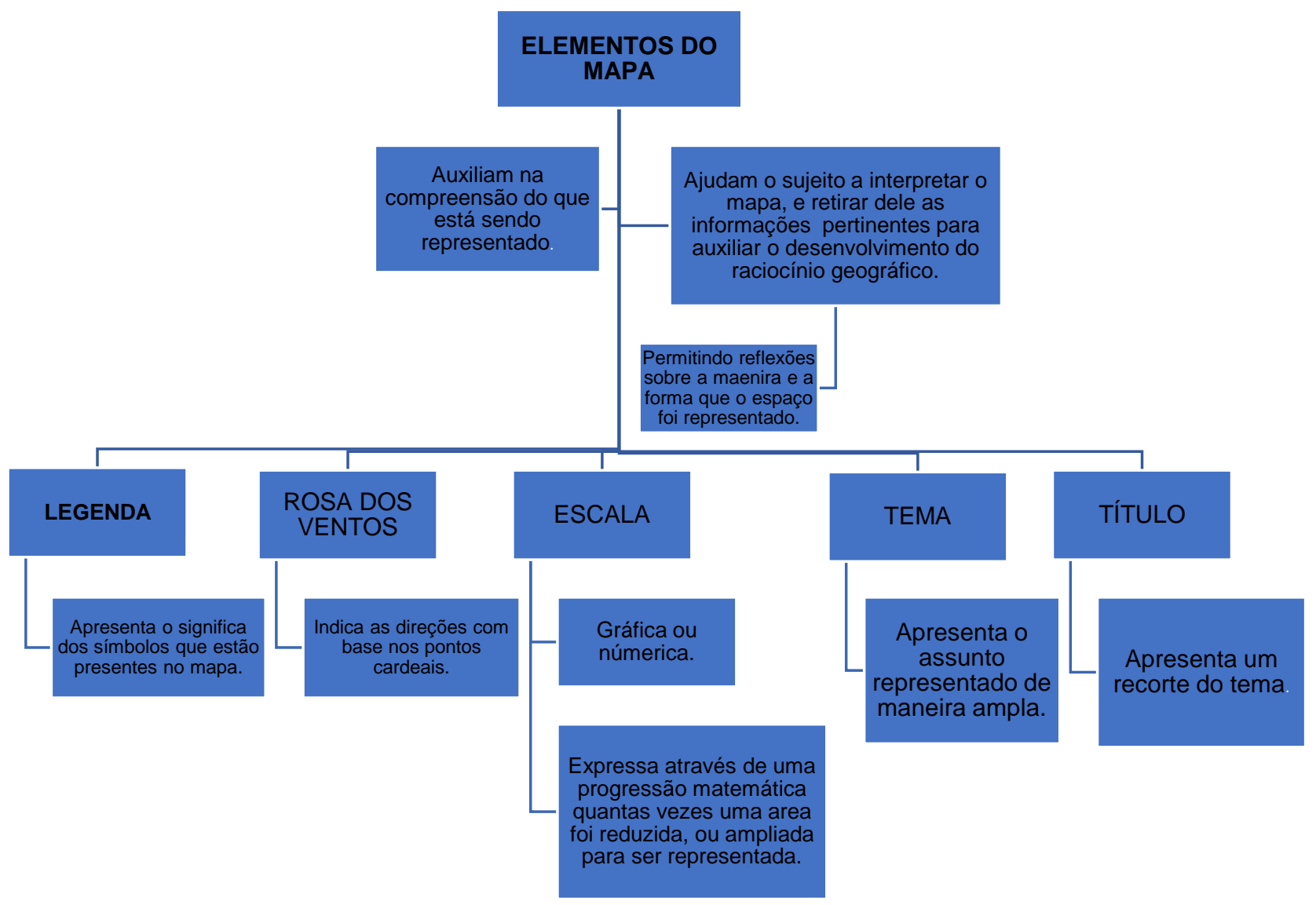

A atividade a seguir tem o objetivo de compreender quais são os elementos da cartografia oficial, (aquela que é composta por um conjunto de normas e regras essenciais na compreensão de um mapa), que podem auxiliar na leitura e interpretação do tema que está sendo representado. Buscamos, através desta interpretação, chegar ao objetivo maior, que é ler o fenômeno e analisá-lo através do raciocínio geográfico.

Ela foi dividida em dois momentos. No primeiro, os alunos tiveram contato com o mapa, e antes de terem um estudo aprofundado dos elementos que são essenciais para lê-lo segundo a cartografia oficial, foi pedido que identificassem os mesmos, buscando resgatar o conhecimento prévio que tinham do tema.

O segundo momento consistiu na reaplicação da atividade em grupo, após eles terem um maior acesso e conhecerem os elementos do mapa de 
maneira detalhada, compreendendo seus conceitos e suas respectivas colaborações na leitura e interpretação. A seguir, temos a atividade proposta que serviu de mediação desta segunda situação de aprendizagem:

Observe o mapa abaixo e identifique quais são os elementos essenciais para a leitura e interpretação dele.

\section{FIGURA 6. Mapa do Brasil: Grandes Regiões}

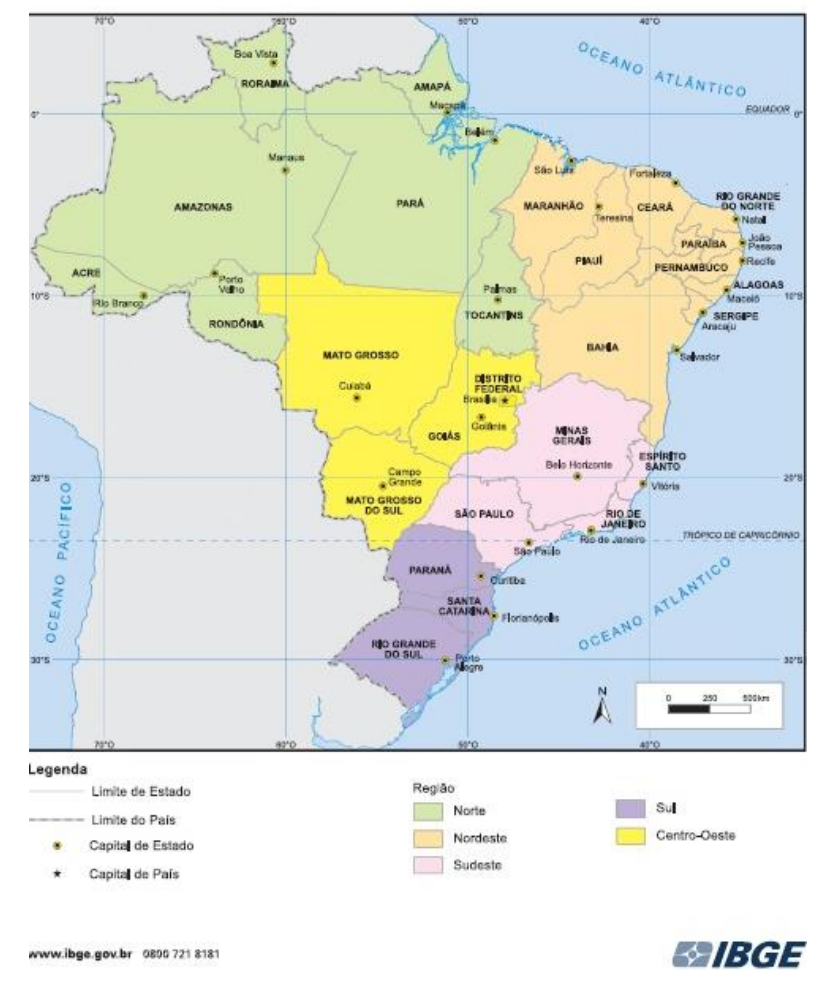

Após a aplicação desta atividade, foi possível observar alguns pontos importantes, como mostra o gráfico abaixo:

GRÁFICO 2: Elementos do mapa identificados pelos estudantes 


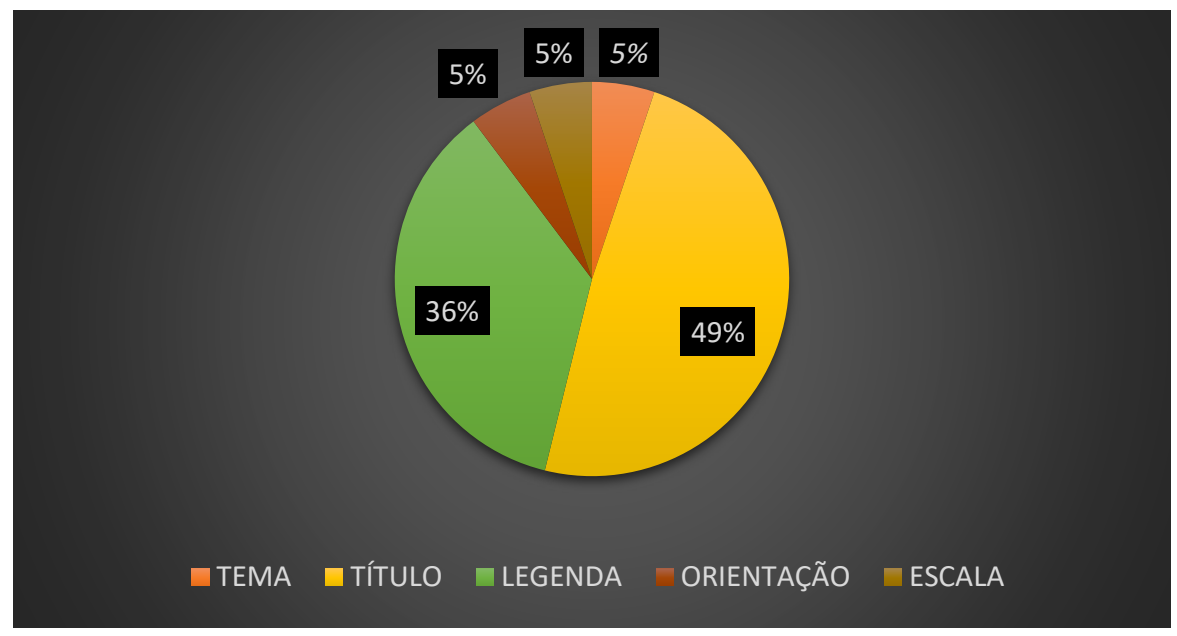

Fonte: elaborado pelo autor, abril de 2019.

Observando o gráfico com os resultados, é possível perceber que a maioria dos alunos, na primeira aplicação da atividade, ainda não conseguia compreender quais eram os elementos que estavam presentes no mapa. Isso pode ocorrer devido a alfabetização cartográfica não ter sido efetivada nos anos iniciais do ensino fundamental. É importante também ressaltar que alguns conseguiram identificar a legenda e o título. Esses elementos estão mais presentes em alguns mapas (como é o caso do que foi utilizado na atividade), o que facilitou para alguns reconhecê-los.

Além disso, durante os diálogos estabelecidos na aplicação da atividade, foi possível perceber que os alunos tinham dificuldades de observar o mapa e retirar dele informações mais profundas, principalmente aquelas vinculadas a localização e distribuição dos fenômenos representados. Isso tem relação direta com a alfabetização cartográfica, pois sem ela o sujeito pouco consegue compreender a linguagem cartográfica. Para que aconteça essa assimilação é preciso então entender que existe um "alfabeto cartográfico". Para tanto a cartografia vai se utilizar de um conjunto de símbolos, que tem formas, texturas e cores para conseguir representar os fenômenos expressos nos mapas.

[...] a cartografia pode, legitimamente, ser considerada como uma linguagem. Linguagem universal, no sentido em que utiliza uma gama de símbolos compreensíveis por todos, com um mínimo de iniciação. (JOLY,1990,p.13) 
Todos esses símbolos existem para facilitar a compreensão do leitor. Por isso, se ele não consegue entender seu significado, a leitura seguirá comprometida, impedido o mesmo de enxergar o fenômeno representado.

Para colaborar com a assimilação destes conceitos, foram realizadas aulas expositivas, leituras e atividades que apresentaram aos alunos esse conjunto de símbolos, pontos e cores, que ao longo dos dias possibilitaram a compreensão de que sem os elementos do mapa, a leitura e interpretação do mesmo seria limitada, deixando-os sem detalhes importantes do fenômeno que estava sendo representado, dificultando a sua leitura, pois segundo Gomes ( 2017,p.131) " os "quadros" na Geografia são "desenhados" para podermos pensar e descobrir coisas novas, e não apenas para ilustrar ideias conhecidas". Assim, se o sujeito não consegue ter acesso a essa descoberta, o sentido de ter o mapa em seu cotidiano se perde. Dessa maneira, reforça-se a importância de fornecer os elementos essenciais para a sua leitura.

Após essa reflexão e inserção dos alunos neste processo, partimos para um segundo momento, buscando observar esses pontos através de uma atividade em grupo. Os estudantes foram divididos em 5 grupos. Cada grupo sorteou um elemento do mapa para estudar. Em seguida o mapa foi projetado na parede da sala sem os elementos.

O objetivo era fazer com que cada grupo fosse adicionando o elemento ao mapa e explicando a sua importância. Ao final cada, grupo entregou um pequeno texto, onde havia as reflexões acerca da importância dos elementos, como facilitadores da leitura do mapa. A partir da escrita de cada grupo, elaborei um pequeno resumo do que eles apontaram como conceitos para compreensão dos elementos do mapa.

Abaixo, segue a conceituação dos alunos bem como as minhas considerações sobre os elementos do mapa e sua importância, com base no que foi estudado e debatido acerca da cartografia oficial.

Os elementos do mapa são muito importantes para que a gente compreenda o que está sendo mostrado. Os elementos são: tema, título, legenda, escala e orientação (rosa dos ventos). 
Os símbolos terão como base para identificá-los, o que chamamos de legenda. A legenda vai possibilitar que a leitura do mapa aconteça de maneira mais simples, já que não é possível memorizar todos os símbolos existentes.

Eles se dividem em quantitativos e qualitativos. Os quantitativos têm o objetivo de ajudar o leitor a separar um rio de uma estrada, por exemplo. Os quantitativos apresentam uma noção mais organizacional, como uma sequência, tamanhos de formas geométricas são bastante utilizados.

Então, a legenda do mapa trará o significado da cor, símbolo ou textura que está representada, dando ao leitor do mapa a possibilidade de interpretar o fenômeno. Observe no quadro abaixo, um exemplo desses símbolos:

Figura 7: SÍMBOLOS QUALITATIVOS E QUANTITATIVOS

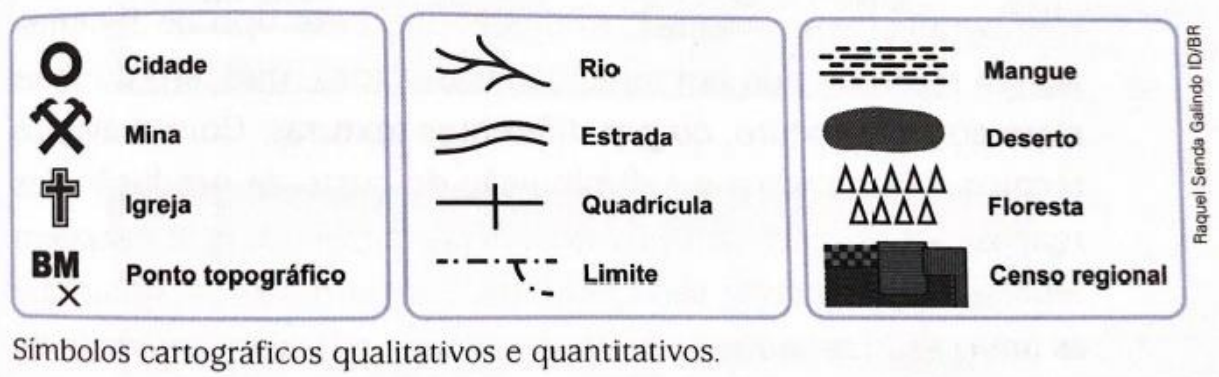

Guerreiro, 2013.

Além da legenda outro elemento importante para a leitura de um mapa, é a observação do seu tema e título.

O tema vai mostrar de maneira mais ampla o conteúdo que o mapa aborda, e o título o seu recorte, por isso, se o sujeito não consegue identificar o tema e o título, dificilmente ele compreenderá qual situação foi representada no mapa.

Os temas dos mapas podem ser diversos, dentre eles podemos destacar: os físicos, políticos, econômicos e humanos. Cada um deles representando seus fenômenos através de símbolos, core e pontos, que colaborem com uma melhor compreensão por parte do leitor, do que está sendo abordado. 
A escala é um outro conceito importante para a compreensão do mapa, pois ela aborda uma relação de proporção, ou seja, ela nos mostra as reduções que aconteceram para que o fenômeno fosse representado. A escala da qual estamos nos referindo, é a cartográfica, por isso, é preciso compreender que ela indica a redução do tamanho de um objeto para que o mesmo possa ser representado, e entendido, por isso essas imagens que são representadas em diversas e variadas escalas, como afirma Gomes ( 2017,p.133) "são resultado de escolhas e critérios que reúnem condições para tornar visíveis determinadas coisas. No ato de ver, há escolhas, há critérios, há condições".

Então, a escala vai representar aquilo que desejo compreender, ou aquele fenômeno que pretendo mostrar para um determinado grupo. Se eu desejo esconder algo, também vou utilizar uma escala que possibilite isso. A escala não é apenas uma escolha matemática aleatória, ela atende um determinado posicionamento, para se chegar em um determinado fim.

Em um mapa existem dois tipos de escalas, a gráfica e a numérica. Elas buscam estabelecer uma relação entre o comprimento dos objetos de estudo em um mapa e a sua forma no mundo real.

\section{Escala numérica}

A escala numérica estabelece a relação entre o comprimento no mapa e a distância no terreno por meio de número. Exemplo de escala numérica:

$1: 100.000$

Uma escala numérica de 1 para 100 mil significa que cada centímetro no mapa corresponde a 100 mil centímetros no mundo real.

\section{Escala gráfica}

Outro tipo de escala é a escala gráfica. Nesse caso, utiliza-se um segmento de reta graduada para estabelecer a relação entre o mapa e a vida real. Exemplo de escala gráfica:

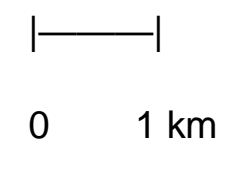


Se esse exemplo aparecer em um mapa e a medida desse segmento for 1 centímetro, significa que $1 \mathrm{~cm}$ no mapa equivale a um quilômetro na vida real.

Outro elemento muito importante que está presente no mapa, é a localização, esse elemento é representado pela rosa dos ventos, e tem o objetivo de ajuda o sujeito se orientar.

Para isso, no mapa, a rosa dos ventos é a representação gráfica que serve para indicar a orientação através dos pontos cardeais, colaterais e subcolaterais. Desta forma, pode-se entender que tendo esse conhecimento, a leitura do mapa, será muito mais prática, e a leitura do fenômeno representado também. Essa atividade se tornou a base para que as outras que foram desenvolvidas obtivesse êxito, dessa forma, retomar essa conceitualização foi algo constante em todo o processo, pois não são todos os sujeitos que conseguem assimila-los de imediato, alguns vão entendendo no meio do caminho sua importância.

Dessa forma, ao final do desenvolvimento da situação de aprendizagem, foi possível perceber que a assimilação desses conceitos colaborou para que os estudantes compreendessem os elementos importantes que compõem 0 mapa e que contribuem na leitura e entendimento dele. Não se tratou, porém, de um entendimento apenas formal destes elementos. Ao contrário, os estudantes conseguiram perceber a razão dos elementos serem importantes para leitura do mapa o que, em nossa perspectiva, significou um importante avanço no processo de alfabetização cartográfica e compreensão das várias representações espaciais existentes. Os desdobramentos desta atividade também são percebidos nas atividades que se seguem nesta pesquisa, bem como a análise delas, pois abordam diretamente o uso do mapa no cotidiano escolar.

Um dos pontos frágeis desta situação e que gostaríamos de destacar diz respeito a escolha de apenas um tipo de mapa para análise dos estudantes, o que pode reforçar uma lógica de cartografia e de representação espacial em detrimento de tantas outras possíveis. Assim, seria importante na reconstrução desta situação buscar uma maior diversidade de mapas, com diferentes perspectivas e temas representados, possibilitando aos estudantes outras experiências com a amplitude da linguagem cartográfica. Além disso, seria 
importante que a situação fosse mais longa, trabalhando com maior nível de detalhe estes elementos dos mapas, comparando formas diferentes de mapear e, inclusive, questionando se faz sentido todos os elementos presentes em um mapa. Em nossa perspectiva, este aprofundamento poderia levar os estudantes a problematizarem o mapa como uma representação, repleta de intencionalidade e sentidos.

\subsection{SITUAÇÃO DE APRENDIZAGEM 3. Perfil topográfico e as representações tridimensionais do espaço geográfico.}

A atividade a seguir foi aplicada logo após a conceituação do tema e tem o objetivo de permitir que os alunos aprendam a ler e a diferenciar as representações tridimensionais do espaço geográfico. Espera-se também que os estudantes façam a leitura topográfica através das curvas de nível, diferenciando as duas representações, que estão aqui na forma de quadros, conforme a concepção de Gomes (2017,p.131) "os quadros na Geografia são "desenhados" para podermos pensar e descobrir coisas novas, e não apenas para ilustrar ideias conhecidas".

A atividade foi pensada para auxiliar a prática de identificação dos elementos do mapa na hora de realizar a leitura dele. Assim, serve para observar o que foi compreendido do tema e, também, analisar se os aspectos técnicos da cartografia formal dão conta de auxiliar nessa leitura.

É importante salientar que, como apontamos em diferentes momentos desta dissertação, os estudantes já trazem com eles experiências de aprendizagens tanto de outros momentos escolares, como aqueles que desenvolveram lendo a paisagem cotidiana, através do raciocínio geográfico. Como aponta Gomes (2017)

A ideia de paisagem nos ensina a olhar de outra forma, nos ensina a ver coisas, conteúdos, valores, onde parecia antes nada haver de admirável. Desde então, parece que aprendemos a apreciar e que incorporamos, de modo quase natural na vida cotidiana, os valores, os conteúdos contidos nesses fragmentos expostos ao olhar. (p.134) 
Dessa maneira fazer a leitura da paisagem, com base nos conceitos aprendidos na aula, possibilita o desenvolvimento de novas de enxergar e compreender os fenômenos, ampliando a correlação de variáveis e escalas espaço-temporais da realidade. No caso do uso dos mapas de curva de nível e dos blocos diagrama, é possível fazer uma leitura da realidade mediante a observação de aspectos tais como altura, profundidade e largura.

$\mathrm{Na}$ atividade a seguir, os alunos identificaram as representações, bem como as diferenças que existem em cada uma dela, para conseguir fazer uma leitura do espaço e a maneira como ele é ocupado, analisando as causas e consequências decorrentes desta ocupação, permitindo refletir sobre as razões que levam a essa ocupação.

A seguir, temos a atividade proposta:

As imagens a seguir são duas representações do espaço. Observe-as e responda o que se pede:

IMAGEM A

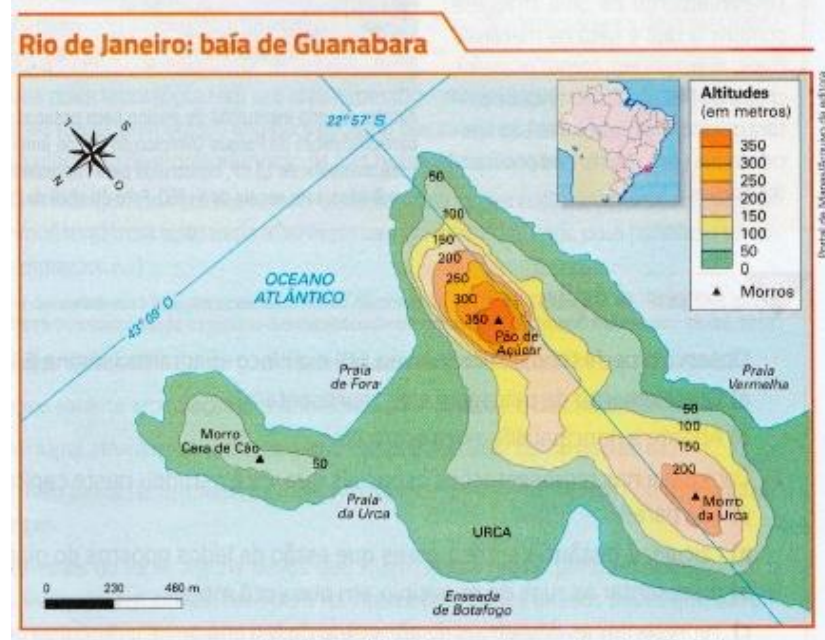

Fonte elaborado com base em FERREIRA, G. M. L. Moderno atias geografico. 6. ed. Sáo Paulo:

FIGURA 8: MAPA BAÍA DE GUANABARA
IMAGEM B

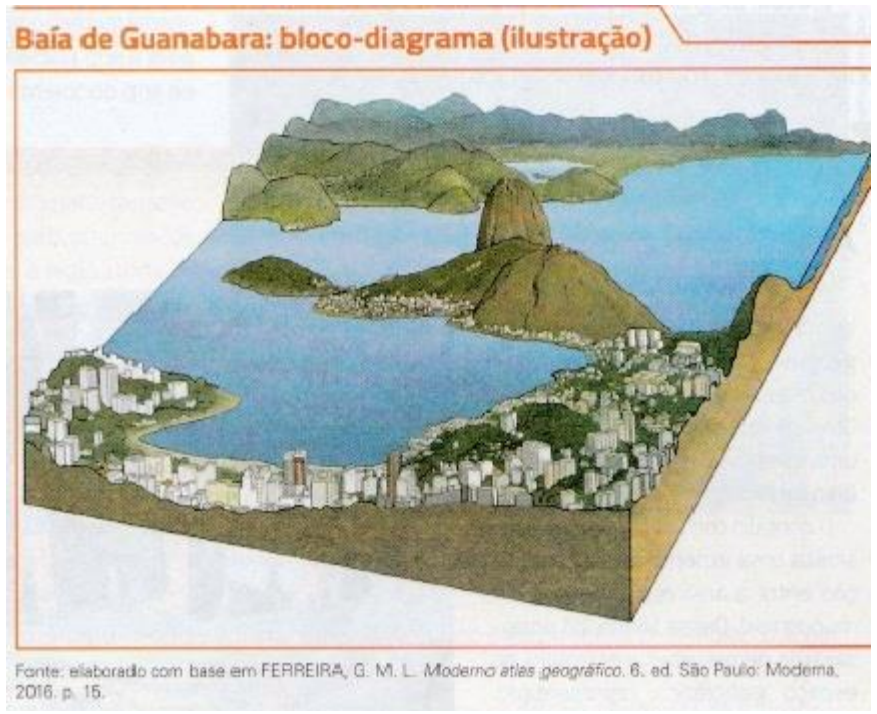

FIGURA 9: BLOCO DIAGRAMA

a) Qual tipo de representação está presente na imagem A?

b) Aponte a principal diferença entre a imagem $A$ e $B$.

c) É possível identificar áreas de risco observando as imagens? 


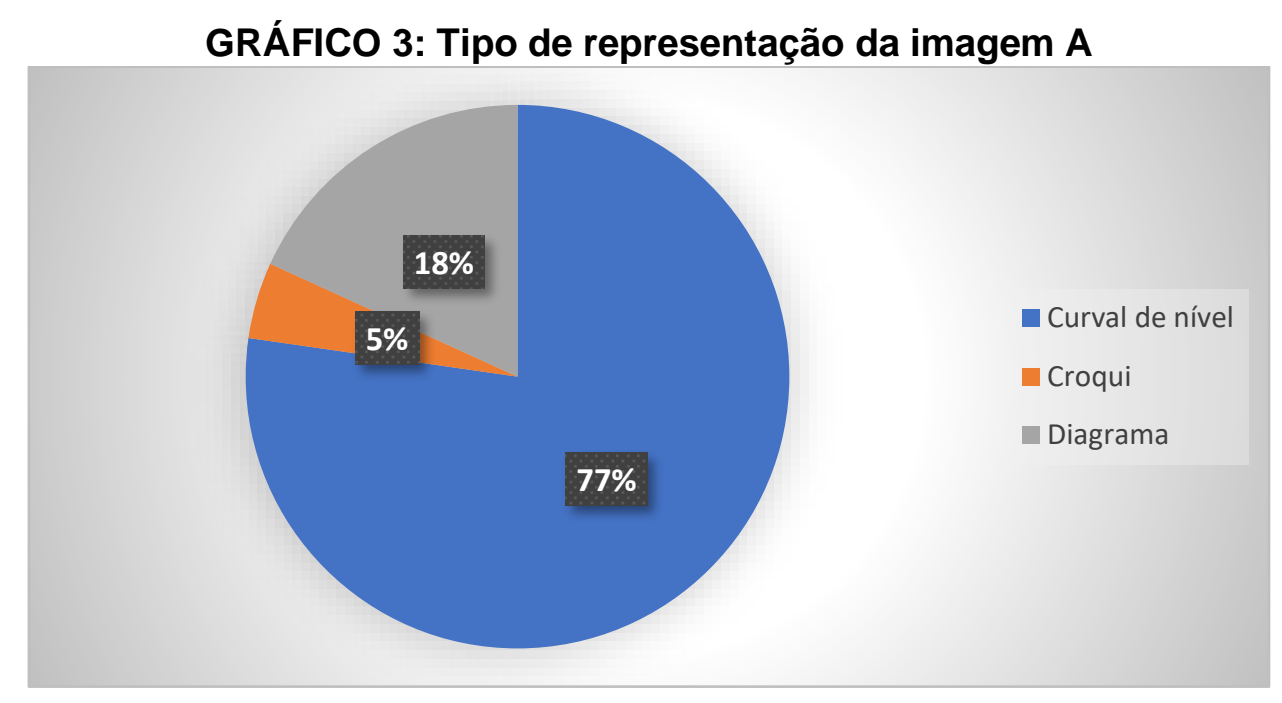

Fonte: elaborado pelo autor, abril de 2019.

Como é possível observar a maior parte dos estudantes identificou a figura A como um mapa de curva de nível. Essa identificação tem relação com as discussões que foram levantadas previamente que mostravam que a curva de nível é o nome das linhas imaginárias que agrupam as áreas de um terreno com mesma atitude e, através delas, é possível que se elabore um mapa topográfico.

O mapa topográfico mostra a diferença de atitude da área. As cores mais escuras indicam áreas mais altas e com maior declividade e as mais claras áreas mais planas e mais baixas. Por meio deste tipo de representação é possível, então, evidenciar melhor os planaltos, planícies, depressões e montanhas.

O perfil topográfico geralmente apresenta uma escala horizontal que serve para mostrar a extensão da área que foi representada e uma escala vertical para mostrar a altitude dos locais. Quando foi perguntado a diferença entre um perfil topográfico e um bloco-diagrama, a maior parte dos alunos se dividiu na seguinte definição: a figura $A$ tem uma característica bidimensional, ou seja, ela aponta apenas a altitude do espaço representado, sendo mais alta e mais baixa, utilizando uma escala de cores para ajudar na compreensão do espaço que está sendo representado.

A figura B apresenta uma superfície tridimensional, com mais características e mais cores. Essa representação é uma forma mais próxima de 
uma fotografia. A escolha do lugar também facilita na hora de observar atentamente essa imagem, pois, por ser uma cidade (Rio de Janeiro) bastante conhecida dos estudantes, permite que façam observações sobre a importância do lugar, bem como as contradições que ele apresenta, utilizando os conceitos e categorias para aprofundar o olhar sobre o que está sendo observado.

Por isso, é importante trazer imagens que eles tenham algum tipo de familiarização. Se não for possível, por exemplo, imagens do bairro, buscar elementos que estejam mais presentes em suas vidas auxilia na compreensão, pois acaba trazendo a ideia de proximidade, bem como a relação afetiva e de pertencimento, fundamentais na construção de processos significativos de ensino-aprendizagem em geografia.

Em uma das discussões promovidas na questão $B$, foi possível discutirmos sobre a paisagem. Alguns alunos levantaram a questão da transformação da paisagem da figura $B$, bem como a distribuição dos elementos que se encontram na cidade do Rio de Janeiro.

Essa discussão tem relação com os conceitos que aprendemos em momentos anteriores e os alunos quiseram demonstrar que a área presente no bloco diagrama, em outro momento, possuía características diferentes e, com o passar do tempo, foi sofrendo transformações. Observando o bloco, isso não é possível de compreender, pois ele aponta apenas um momento daquela paisagem, porém as relações que eles fizeram estavam além do que foi exposto no bloco, refletindo a compreensão de que as paisagens estão em constante transformação. E, como afirma Gomes (2017.p.134) "isso corresponde de algum modo a convocar a imaginação dos alunos a partir de imagens para ensinar a Geografia", reforçando a ideia de que enxergar o que está sendo representado possibilita reflexões sobre aquela representação, inclusive para além delas.

Alguns também mencionaram o fato de que os elementos naturais da cidade acabaram se misturando aos culturais, dando mais visibilidade ao turismo. Para reforçar essa ideia utilizaram o Cristo Redentor e o lugar onde ele está localizado, bem com a Baía de Guanabara, importante ponto do turístico da cidade.

Algumas questões que são importantes para compreender como se dá o processo de apropriação da natureza pela sociedade e como isto está expresso 
na articulação entre o mapa de curvas de nível e o bloco de diagrama, foram feitas após a aplicação da atividade, no momento em que as reflexões da atividade estavam sendo realizadas. Por isso, vale ressaltar que elas foram de extrema importância para colaborar no desenvolvimento do raciocínio geográfico, uma vez que os estudantes apresentaram certo domínio de conceitos da geografia, como o de paisagem cultural e natural, utilizando-os na construção de seus argumentos para interpretar as imagens e mapas apresentados durante as aulas. Tais conceitos, inclusive contribuíram para que os sujeitos pudessem construir interpretação sobre as ocupações espaciais que existem na cidade do Rio de Janeiro e suas possíveis lógicas de localização e distribuição (quais são os tipos de ocupações existentes nos pontos mais altos da cidade do Rio? Quais são as que ocorrem nos pontos mais baixos?). No entanto, é importante ressaltar também os limites destas representações na elaboração de correlações espaciais mais complexas como, exemplo, entre distribuição das ocupações e condição socioeconômica da população. Além disso, os resultados da ocupação não estão visíveis nas representações, o que não impede de serem inferidos a partir de problematizações trazidos pelo docente e pelos estudantes. Todas essas questões podem ser disparadoras de raciocínios geográficos complexos, pois podem possibilitar aos estudantes interpretações da relação sociedade e natureza e sua expressão espacial.

Assim, "a aprendizagem em Geografia possibilita aos sujeitos a pensar as espacialidades dos fenômenos tanto a nível local quanto global" (ASCENÇÃO, 2014), pois eles irão perceber que existem características diferentes na ocupação do espaço das cidades. Uma cidade litorânea nem sempre vai ter em suas margens condomínios de luxo. Em alguns casos, o que se vê são ocupações precárias, e pessoas que precisam viver um modo de vida mais simples. Olhar e refletir sobre se faz a partir das relações que vão sendo construídas a partir do raciocínio geográfico, que amplia a forma dos estudantes de entenderem o mundo em suas diferentes escalas espaço-temporais.

Todas essas organizações de pensamento têm a ver com o que diz Girotto (2015, p.82):

Destaca-se, então, a necessidade que o estudante, ao se apropriar dos conceitos, conteúdos, linguagens e ferramentas da 
geografia, possa construir um raciocínio geográfico sobre o mundo em que vive. Não se trata, dessa forma, de formar um sujeito que apenas entende de geografia, mas pouco sabe sobre o mundo em que vive.

Dessa maneira percebe-se que a construção do pensamento geográfico vai acontecendo e aos poucos ele vai ser tornando um instrumento cultural, que colabora e muito na compreensão da realidade e, também, na transformação da mesma, colaborando para ampliação do raciocínio geográfico, já presente nas observações feitas pelos sujeitos.

Quando os alunos foram perguntados se era possível identificar as áreas de risco observando as figuras $A$ e $B$, a resposta que predominou foi a de que sim, como mostra o gráfico abaixo:

GRÁFICO 4: É possível observar áreas de riscos nas figuras A e B?

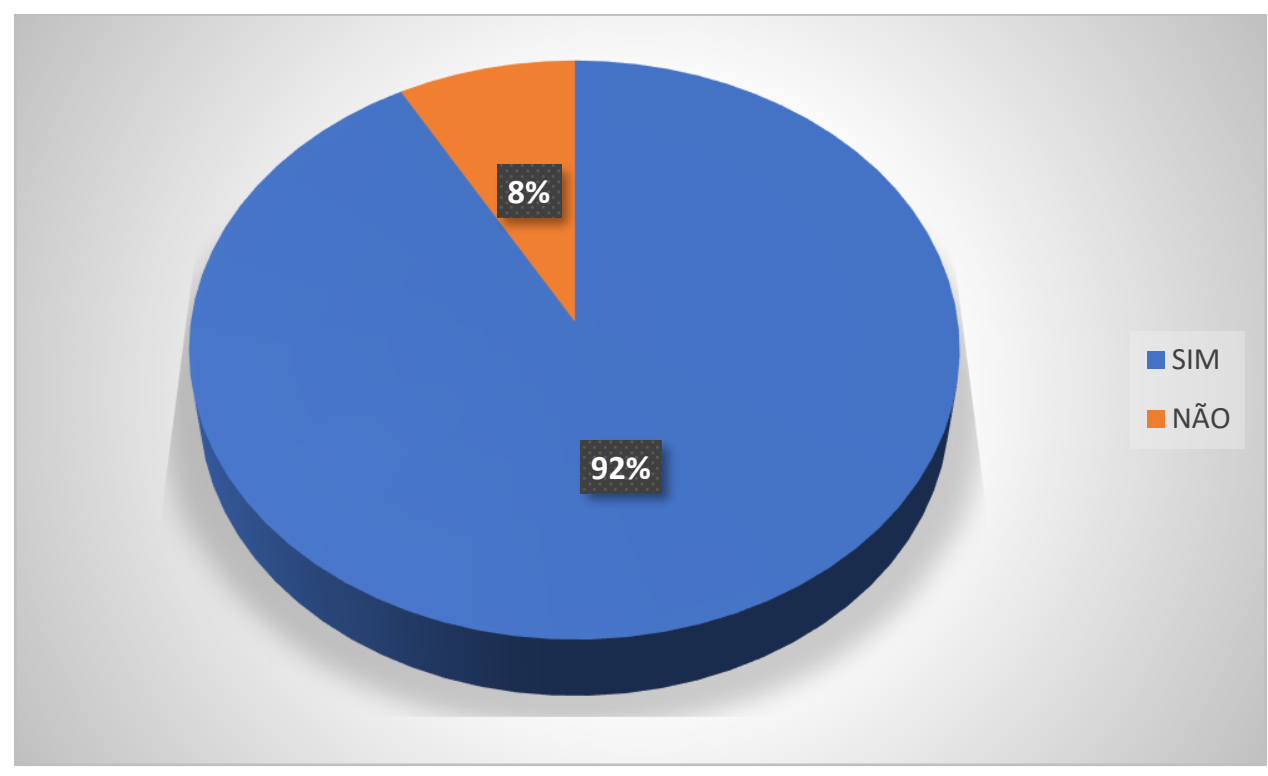

Fonte: elaborado pelo autor, abril de 2019.

As discussões em torno das áreas de risco abordaram o relevo da cidade do Rio de Janeiro. Para chegarmos nesse entendimento, foi trabalhado com os sujeitos o conceito de áreas de risco, mostrando-lhes, que algumas estruturas geomorfológicas, são inapropriadas para a ocupação humana, mas que na maioria das cidades, isso não é levado em conta, por causa das condições socioeconômicas dos sujeitos. Grande parte da população não consegue ter acesso, por exemplo, a um terreno em uma área considerada "segura" para morar, e vai se abrigar onde suas condições permitem. 
Dessa forma, a maioria dos alunos se ativeram as construções que estavam localizadas próximas a encostas dos morros, reforçando a ideia de Gomes (2017,p.133) " a imagem faz com que algo, que de outra forma não seria nem mesmo percebido, se torne visível". Isso ajuda a compreender, porque eles chegaram na ideia de que essas construções estariam comprometidas, caso o volume das chuvas na região fosse muito elevado. E segundo as observações feitas por eles, as pessoas que estavam distantes dessas áreas estariam mais seguras.

O que alguns não conseguiram associar, neste momento, foram as razões que levaram algumas pessoas a estarem expostas, morando em áreas de encostas de morros. Essa reflexão foi, então, trazida através da minha intervenção, para conseguir identificar o que eles pensavam sobre isso. Dessa forma alguns começaram a resgatar os conceitos e experiências e alguns enfatizaram as seguintes questões:

"Eles moram nesses lugares porque não tem dinheiro para comprar uma casa em lugar seguro"( Aluno 1- $6^{\circ}$ ano $B$ )

"Não tem um bom emprego, e vivem onde conseguem"( Aluno 2- $6^{\circ}$ ano C.)

"A cidade tem bairros muito caros, e nem todo mundo pode morar lá, porque o salário é desigual" ( Aluno 3- $6^{\circ}$ ano B.)

Diante das respostas, é possível perceber que a ideia que eles têm sobre a ocupação do espaço está ligada a distribuição de renda e que a leitura da paisagem passa por esse viés, mostrando que não é apenas um acaso o fato das casas estarem dispostas daquela forma. Existe uma premissa maior que colabora para que as pessoas vivam naqueles espaços e corram riscos, caso, por exemplo, o volume de chuva seja elevado e resultem em deslizamento de terra.

Alguns levantaram os constantes problemas que a cidade e, também, o estado do Rio de Janeiro apresentam por conta das chuvas. E isso foi lembrado por meio de reportagens, que na época, estavam relatando os deslizamentos de 
terra, que ocorreram após grande temporal na cidade, ocasionando acidentes de carro, desmoronamento de prédios, levando a morte de várias pessoas.

Foi possível perceber que a o raciocínio geográfico estava presente na análise desse fato e a linguagem cartográfica, através do bloco-diagrama e do perfil topográfico, auxiliou elaboração das conclusões dos estudantes, pois a partir do momento que eles observaram as representações, foi possível fazer as conexões com a realidade, discutir as causas do problema, bem como suas possíveis soluções, construindo correlações cada vez mais complexas entre diferentes fenômenos espaciais. Como afirma Gomes(2017,p.139) "essa estrutura, visível no mapa ou, podemos acrescentar, em qualquer quadro geográfico, corresponde a uma sugestão de compreensão daquilo que está sendo apresentado".

Após elaboração e análise da sequência, foi possível pensar também nas fragilidades que ela traz, por ter sido desenvolvida no cotidiano escolar, apontando que os desafios são imensos neste campo. Dessa maneira pensar esse desenvolvimento neste contexto implica também em algumas dificuldades, uma delas, por exemplo, é conseguir um tempo de qualidade para desenvolver as sequencias e dar conta das questões burocráticas que existem na sala de aula, assim a aplicação da sequência esbarra na prática cotidiana, que precisou ser repensada e articulada para tentar obter os resultados aqui apresentados.

Uma das fragilidades que posso perceber na sequência aplicada é a não articulação entre cidade do Rio de Janeiro e São Paulo. Neste momento não havia pensado nas potencialidades que isso poderia trazer à discussão. Considero que esta articulação poderia ter trazido mais elementos para a ampliação do raciocínio geográfico, pois traria a discussão para o lugar de vivência dos estudantes, possibilitando, assim, a correlação de fenômenos expressos em diferentes lugares.

Dessa forma, a reformulação da sequência, com a articulação entre estas diferentes realidades espaciais e suas correlações, traria, em nossa perspectiva, outros elementos para serem analisados, como, por exemplo, uma relação entre as ocupações da cidade do Rio de Janeiro e a cidade São Paulo. Também seria possível problematizar a partir da ocupação do bairro no qual a escola está situada, entendendo como ela se deu. Ao dialogar com os lugares de vivência 
dos estudantes, a sequência poderia auxiliar no desenvolvimento do raciocínio geográfico, tanto por partir de temas e fenômenos vividos pelos estudantes, quanto pela elaboração de análises correlacionando diferentes lugares e diversas escalas espaço-temporais.

Dessa forma, mesmo diante dos desafios e dificuldades apresentados, mediante as análises feitas através das sequências, é possível reforçar a ideia de Claval (2015, p.08), que o raciocínio através da Geografia (...) "está presente nas práticas, nas habilidades, nos conhecimentos que todos sempre mobilizamos em nossa vida diária". E que na escola, se ele for incentivado, e trabalhado através da linguagem cartográfica, será um grande aliado no desenvolvimento e ampliação do raciocínio geográfico.

\subsection{SITUAÇÃO DE APRENDIZAGEM 4- MAPA HIPSOMÉTRICO DA CIDADE DE SÃO PAULO}

A atividade a seguir tem o objetivo de fazer 0 aluno olhar para sua cidade com o auxílio de um mapa hipsométrico e conseguir fazer a leitura dos locais tidos como ideais para uma construção sem riscos, refletindo com base nos conceitos aprendidos nas aulas anteriores e, também, nas vivências dos estudantes.

A atividade foi desenvolvida no final do mês de outubro, período em que os alunos já tinham estudado as estruturas do modelado terrestre. Dessa maneira, não foi necessária uma nova aplicação, pois eles já tinham construído raciocínios essenciais para sua realização.

Esta atividade foi importante para ajudar a perceber que, a partir da leitura do mapa, eles conseguem associar os conteúdos, bem como analisar o espaço em questão, apresentando respostas críticas e pertinentes, colaborando com a ideia de que a linguagem cartográfica é uma forte aliada no desenvolvimento do raciocínio geográfico.

A seguir temos a atividade proposta nesta sequência, bem como as análises feitas a partir dela. 
O pai de Pedro deseja comprar um terreno para construir sua nova casa. Para tanto, ele consultou o mapa hipsométrico da cidade de São Paulo, para ajudar encontrar o local ideal para sua construção. A área que está demarcada por um triângulo possui um terreno mais barato. A outra área, que está demarcada por um círculo, apresenta um terreno mais caro.

A partir dessas informações, com a leitura do mapa abaixo, e seus conhecimentos sobre o assunto, responda:

a) O que faz haver a diferença de preços entre estes terrenos?

b) Qual deles tem mais chances de sofrer algum problema futuramente? Qual seria esse problema?

FIGURA 10: MAPA HIPSÓMETRICO DA CIDADE DE SÃO PAULO

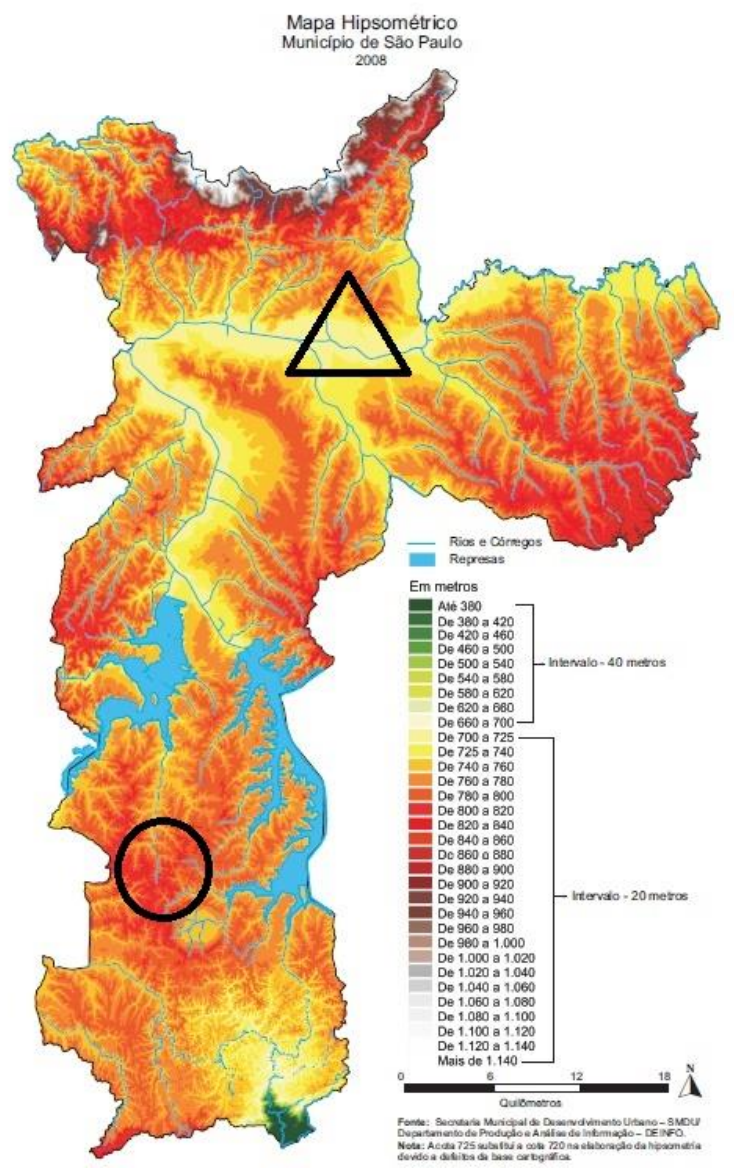

Para conseguir dimensionar as repostas dos alunos foi elaborado um gráfico com as respostas à pergunta da questão A. Ela visava compreender as causas, que levam os terrenos acima demarcados possuírem valores diferentes. 


\section{GRÁFICO 5: o que faz os terrenos terem valores diferentes?}

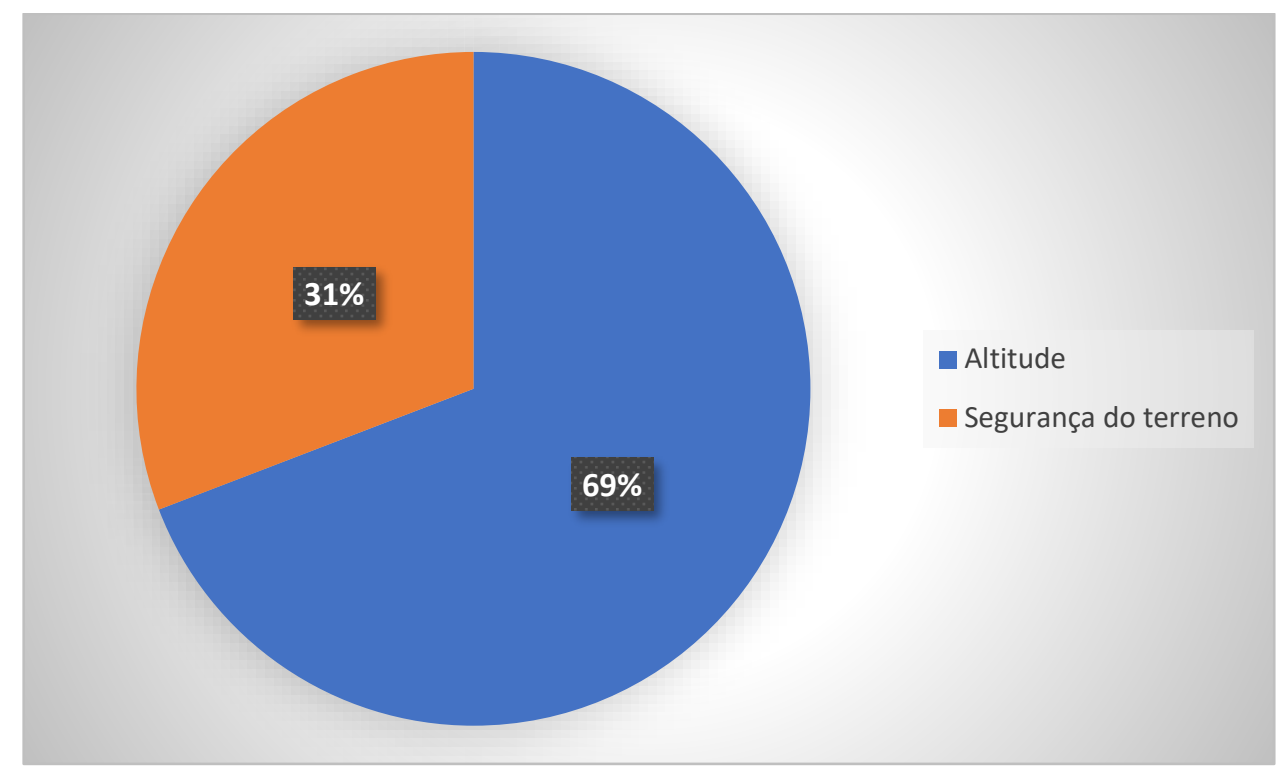

Fonte: elaborado pelo autor, abril de 2019.

Como é possível perceber a maior parte dos alunos atribuíram a divergência do preço dos terrenos ao fator altitude. Algumas respostas traziam o complemento de que o terreno marcado com triângulo está em uma região próxima de rios e, por ser de altitude menor, pode estar sujeito a alagamentos, por isso o valor é mais baixo.

A grande maioria não conseguia, no entanto, identificar qual região da cidade estava sendo representada, mas apenas com os conhecimentos até então obtidos, conseguiram perceber que casas, bairros e ruas são construídos de maneira desigual na cidade, e que isso tem relação com o crescimento, e a organização que há na hora de escolher onde as pessoas podem morar. Essa lógica tem relação direta com a especulação imobiliária, que em determinados pontos da cidade é elevadíssima e impossibilita que a população pobre tenha acesso a esses espaços de moradia.

Algumas respostas ainda apontaram que a maioria das pessoas não tem condições de comprar um terreno caro (o que eles apontaram como mais seguro) e por isso acabam morando onde conseguem.

As respostas também evidenciaram a questão da desigualdade social, pois segundo algumas respostas, se formos prestar atenção, a maior parte das pessoas que sofre com alagamentos de suas casas, não tem casas grandes ou 
bonitas, refletindo assim na maneira como eles enxergam a organização das paisagens, suas contradições e diferenças. Assim, buscar compreender essa maneira de ver a organização da paisagem é também um exercício desse raciocínio geográfico, que vai se desenvolvendo nos estudantes, pois, como afirma Moreira (2007, p. 117) "todo conhecimento em geografia [...] começa na descrição da paisagem". Por isso, associar os pontos de altitude da cidade com as características da paisagem que se forma é uma maneira que eles encontraram para dar sentido ao que estavam enxergando através do mapa hipsométrico.

Uma parte dos sujeitos apresentaram dificuldades em analisar o mapa e compreender o que ele estava abordando. É importante ressaltar que nem todos os estudantes têm essas habilidades bem definidas, e é parte deste processo de pesquisa compreender isso, para que ações para solucionar a questão sejam pensadas.

Porém, a maioria deles acredita que a área demarcada pelo triângulo seja a que apresenta mais riscos, e isso se deve por conta de várias atividades que foram sendo realizadas na sala de aula trabalhando os elementos do mapa, buscando relacioná-los com a realidade.

\section{GRÁFICO 6: área que tem maior probabilidade de apresentar problemas}

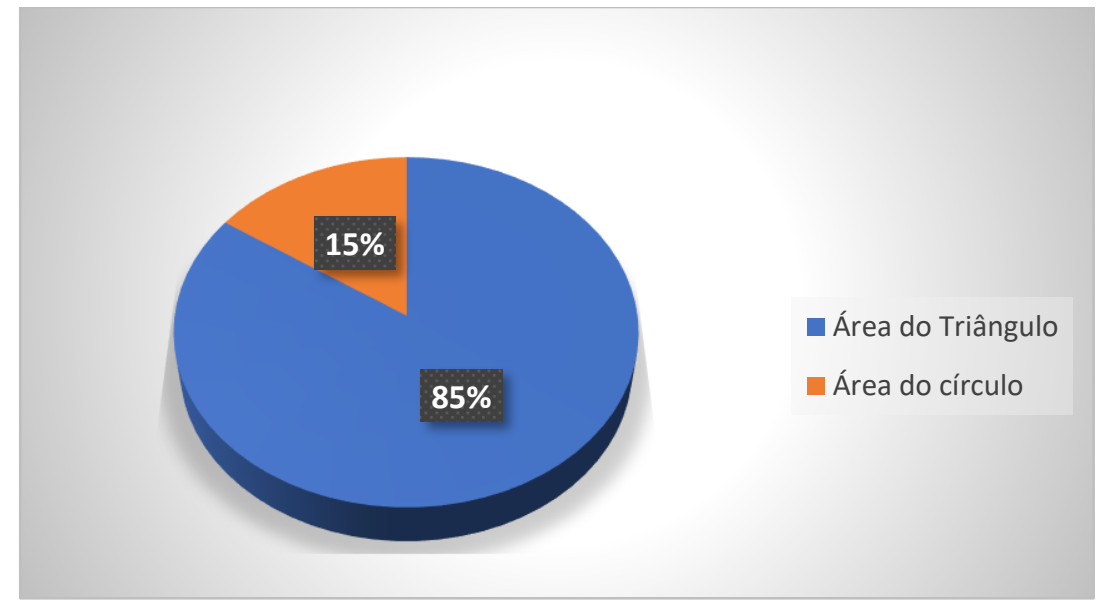

Fonte: elaborado pelo autor, abril de 2019.

Essa escolha foi justificada pelo fato de observarem a altitude e subtenderem que as regiões que estão mais afastadas dos leitos dos rios, sofreriam menos, caso tivesse um volume muito grande de chuvas naquela área. 
Como a área apresenta uma menor altitude, e está próxima de alguns rios, segundo as respostas colhidas, existe mais risco de as casas serem construídas próximas ao leito dos rios, o que facilitaria o alagamento. Alagamento e enchentes, foram os problemas levantados por eles, sendo os alagamentos presentes na maioria das respostas.

Ao questioná-los por que entendem assim, alguns deram exemplos do bairro onde vivem, que está mais perto do rio, e quando chove, a área fica mais fácil de ser alagada, dando exemplos do cotidiano, mostrando que a leitura do lugar é uma grande aliada no desenvolvimento do raciocínio geográfico.

Assim, é possível perceber que aos poucos eles passam a associar os conhecimentos geográficos com as experiências cotidianas, colaborando dessa maneira para a ampliação do seu raciocínio geográfico.

\section{GRAFICO 7: Principais Problemas}

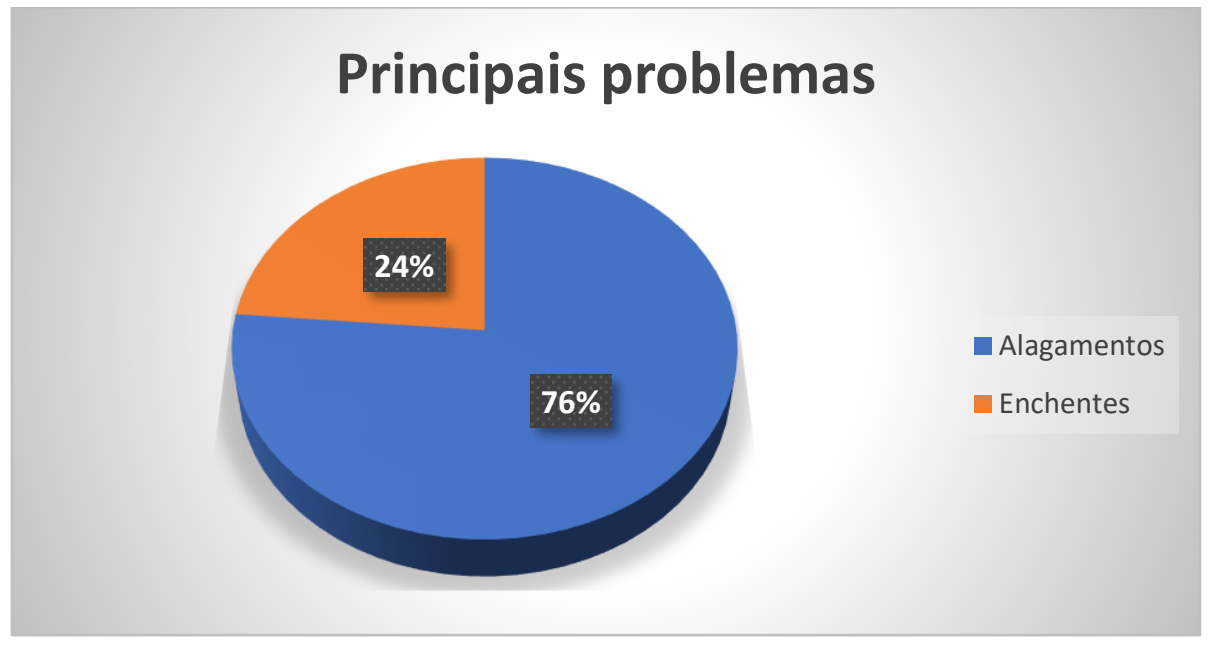

Fonte: elaborado pelo autor, outubro de 2019.

Mais uma vez, a linguagem cartográfica passa a ser uma aliada na descoberta dos sentidos geográficos e sua capacidade de imaginação, deixando de ser meramente uma ilustração e se fortalecendo como possibilitadora de análises, mesmo que em alguns casos, sejam sem muita profundidade, pois, a,

Imaginação é a capacidade de refletir a partir de imagens, que quando são compreendidas como instrumentos para pensar, são elementos chave na possibilidade de gerar imaginação geográfica. (GOMES, 2017, p.141) 
Nesta perspectiva podemos compreender então, segundo Santos (1988, 1996), que "as representações cartográficas têm importância não apenas para localizarmos os dados e as informações geográficas, mas oferecer condições de investigar os indícios que nos explicam os porquês das localizações, o sentido dos sistemas de ações e objetos, serem desempenhados naqueles pontos".

Vale ressaltar, neste contexto, que o mapa vai ocupando um lugar central no aprender a Geografia, sendo um norteador dos questionamentos e das respostas para questões que vão sendo levantadas durante o processo de aprender a ver o mundo, pela ótica da Geografia.

Para finalizar esta atividade, por conta do grande interesse que os alunos desenvolveram sobre o tema, fizemos uma sobreposição do mapa das regiões da cidade de São Paulo sob o hipsométrico, com o objetivo de identificar as áreas que a atividade escolheu como pontos de observação.

Os estudantes quiseram saber quais eram aquelas áreas, para confirmarem se seus posicionamentos estariam corretos sob as possíveis área de alagamento. Alguns alunos mencionaram que próximo da escola tem uma avenida, a Prof. Luiz Inácio de Anhaia Mello, que, quando chove, alaga, e não conseguiram enxergar ela no mapa. Alguns disseram que moram próximo, e que já ficaram ilhados, sem conseguir atravessar, por conta do volume de água.

Não enxergar a avenida Anhaia Melo no mapa, é um ponto chave para pensarmos a questão da escala, pois sabemos que que toda representação é também uma escolha daquilo que vai ser representado. É possível pensar então que a escolha do que vai ser representada passa, para além da questão técnica, pela intencionalidade de quem está produzindo aquele mapa, e em alguns casos, área são suprimidas, em outros elas aparecem, reforçando a ideia de que as produções cartográficas carregam ideologias, e por isso, não são a realidade, mas representações delas. Por isso, a vivência trazida pelos estudantes é importante nesse momento, pois ela pode ser confrontada com o que está ou não está sendo representado, propiciando a reflexão sobre a questão da escala, e seus desdobramentos nas representações dos espaços. Em nossa perspectiva, este é mais um dos elementos que demonstram os raciocínios 
geográficos prévios que os estudantes possuem, bem como as possibilidades de articulação com conceitos e linguagens da geografia escolar que permitem um desenvolvimento mais complexo deste raciocínio. Neste processo, a cartografia, como linguagem, tem um papel central, como vimos demonstrando até aqui.

Foi possível perceber que quando eles enxergam a realidade representada, desenvolvem mais interesse no tema apresentado, pois conseguem se enxergar como parte daquilo que está sendo aprendido. Por isso na tentativa de incentivar esse desenvolvimento, buscamos fazer uma sobreposição, para compreender melhor quais eram as áreas que estavam representadas no mapa.

Para realizar essa sobreposição utilizamos o mapa abaixo que traz as regiões, subprefeituras e distritos de São Paulo e, em seguida, fizemos um levantamento das áreas que estavam selecionadas para o estudo: 


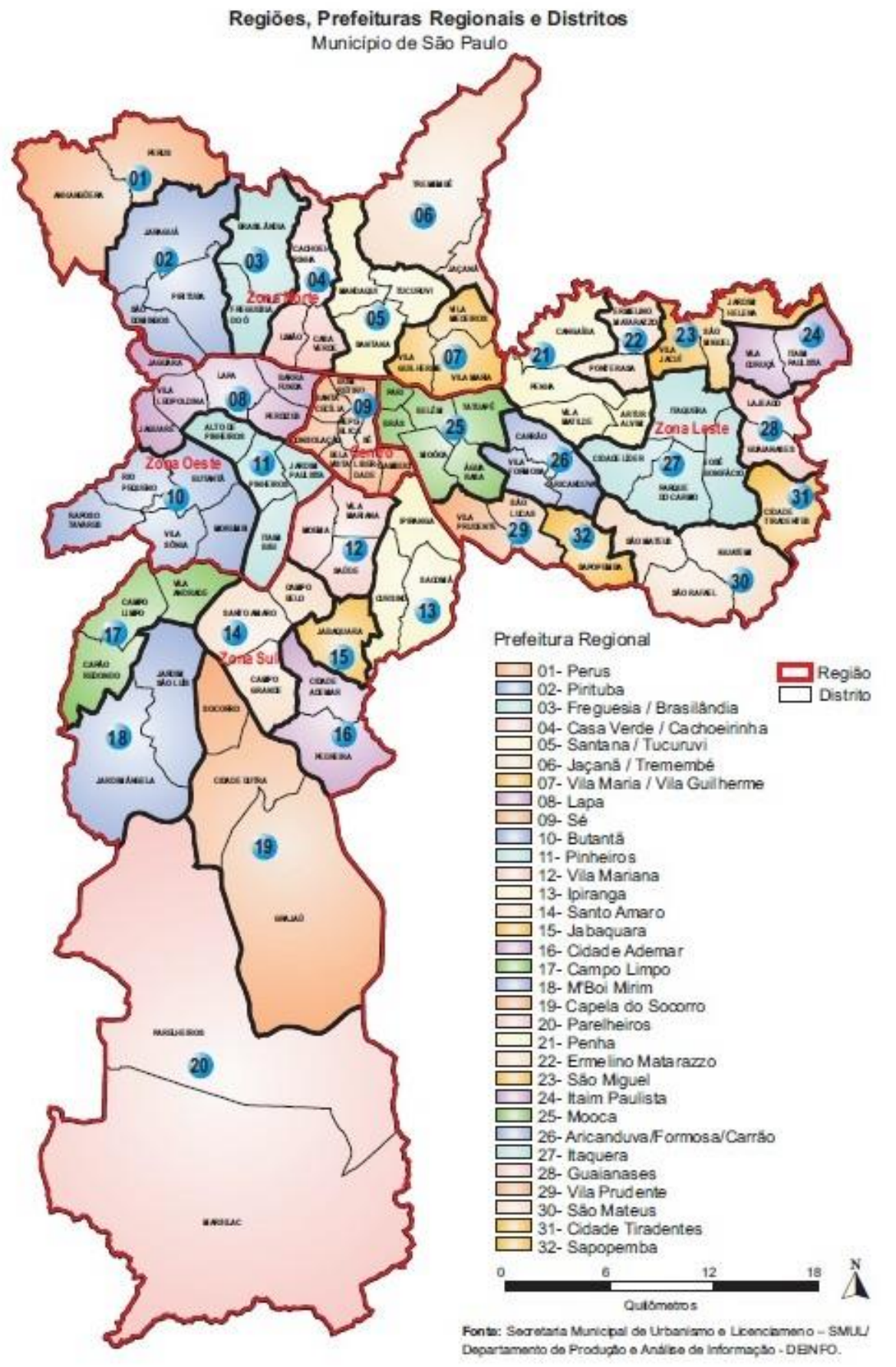

As regiões que foram levantadas como a área circundada pelo triângulo foram: Santana/Tucuruvi, Vila Maria/Vila Guilherme, Sé e Mooca. Essas regiões estão localizadas entre o centro e parte da zona norte da cidade de São Paulo.

Após esse levantamento, os alunos foram pesquisar se tais áreas enfrentavam situações de alagamento, bem como as consequências disso para a vida da população. Para isso, eles procuraram reportagens que traziam a região e o que havia ocorrido para compartilhar com a sala. 
O compartilhamento ocorreu com os alunos reunidos em grupos e apresentando para sala o que encontraram sobre as áreas pesquisadas. Eles apresentaram fotografias e reportagens que comprovavam que as áreas discutidas sofriam com as consequências da altitude e proximidade com rios.

Segue alguns exemplos do que foi trazido para a discussão na sala:

\section{Chuva em SP provoca morte, alagamentos e transbordamento de córregos}

Córregos transbordaram nas zonas Sul e Norte. Bombeiros receberam 106 chamados para enchentes. Uma pessoa morreu em inundação no subsolo de um prédio em Santana.

Fonte: https://g1.globo.com/sp/sao-paulo/noticia/2019/03/03.

FIGURA 13: Imagem da Marginal Tietê em dia de alagamento

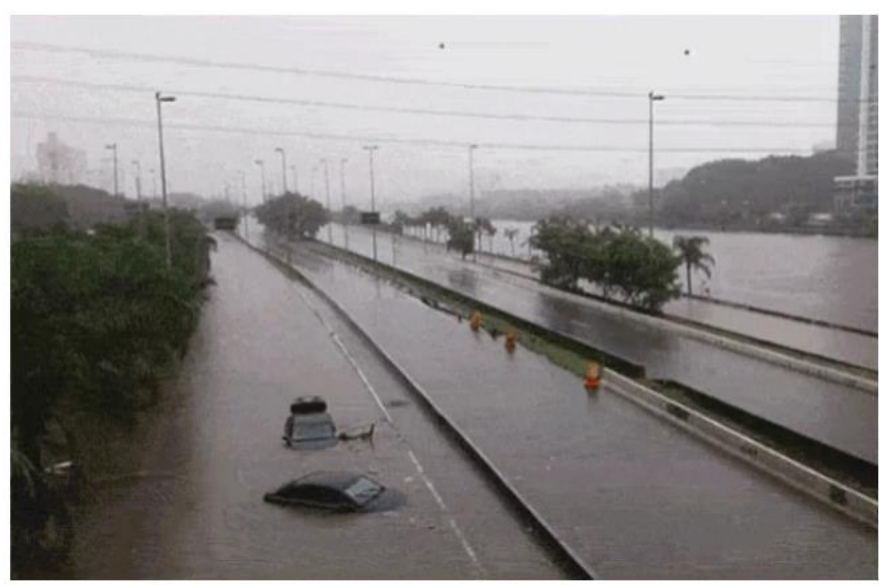

Marginal Tietê próxima à Ponte do Limão, na Zona Norte de SP, alagada de mannhã e à noite desta segunda-feira Marginal Tietê próxima à Ponte do Limão, na Zona Norte de SP, at
Foto: Werther Santana/Estadåo Conteúdo e Celso Tavares/G1

Fonte: https://g1.globo.com/sp/sao-paulo/noticia/2019/03/03. 
Após a apresentação da imagem e trecho de reportagem, com leitura em grupo, foi possível perceber que a análise realizada com o mapa hipsométrico ganhou novas interpretações, uma vez que os estudantes conseguiram compreender a representação e que as cores do mapa estavam representado de maneira real um espaço da cidade, trazendo a sensação de uma aprendizagem com sentido. A leitura do mapa possibilitou que o conhecimento dialogasse com a experiência de vida dos estudantes. Desta maneira, o raciocínio geográfico vai se formando, e a geografia vai tendo sentido na hora de fazer a leitura do lugar, e, consequentemente, da cidade.

Esta atividade foi uma das mais significativas no que se refere a linguagem cartográfica como aliada para a formação do raciocínio geográfico. A maioria dos sujeitos avançaram nesse momento, mas não podemos deixar de mencionar que alguns ainda apresentam grande dificuldade em compreender, e associar as questões estudadas.

Eles conseguiram compreender que o mapa não é uma imagem isolada, sem sentido. A partir do momento que eles entendem como é realizada a leitura, e o que eles podem retirar desta leitura, eles aprendem de maneira significativa, utilizando os conceitos geográficos para chegarem em suas conclusões.

Após refletir, lendo as respostas que eles deram, foi possível pensar uma atividade que buscasse subverter a cartografia oficial, trazendo para eles a possibilidade de criar seus próprios mapas, representando o lugar em que viviam, criando suas próprias convenções, a fim de incentivar sua criatividade e ampliação do raciocínio geográfico. Porém, não foi possível a realização desta, ficando assim, sem desenvolver esse aspecto de uma cartografia do próprio aluno.

A sequência aplicada também apresenta outras fragilidades, que foram percebidas após a sua análise, e isso é importante porque colabora com 0 processo de produção do conhecimento, e auxilia pensar novas possibilidades de aprendizagens.

Um dos pontos que não foram muito aprofundados com os sujeitos nesta sequência foi a relação entre riscos ambientes e desigualdades socioespaciais, 
o que dificultou a leitura mais crítica e profunda de algumas representações, bem como a construção de correlações mais complexas entre diferentes fenômenos socioespaciais.

Algumas questões não ficaram tão claras quanto aos caminhos que eles usaram para chegar nas respostas, mas tem relação com o cotidiano dos sujeitos estudados, por exemplo, como é o caso da questão de: por que os estudantes consideraram o triângulo a área de maior risco? Isso se torna mais claro para eles, por conta do lugar em que vivem, e do conhecimento que adquiram observando as consequências da chuva, em uma área próxima de rios.

Isso nos ajuda a perceber que o raciocínio geográfico não está apenas limitado ao contexto da geografia escolar, e que ele pode ser desenvolvido através de observações cotidianas, mas na escola pode ser ampliado, e trazer mais elementos para compreender o fenômeno em sua totalidade.

Outro elemento de fragilidade que poderia ser repensando na reconstrução da sequência diz respeito ao conceito de produção do espaço como central no entendimento da localização e distribuição dos fenômenos da realidade. Como foi possível perceber, pela sequência proposta, os estudantes conseguiram desenvolver correlações simples entre fenômenos (neste caso, altitude e risco ambiental). Em nossa perspectiva, esta correlação simples ainda está na lógica da organização do espaço, a mesma que pode ser encontrada na sequência anterior. Ao trabalharmos com a ideia da produção do espaço, poderíamos problematizar os diferentes processos e agentes que devem ser considerados no entendimento da localização e distribuição dos fenômenos. Isto poderia contribuir para ampliar a densidade das correlações produzidas pelos estudantes e, consequentemente, contribuir para o desenvolvimento de raciocínios geográficos cada vez mais complexos.

No entanto, sabemos das dificuldades que é trabalhar com conceitos complexos e abstratos com estudantes do 6ํㅡㅁ ano, o que nos levou a uma certa cautela no processo de elaboração da sequência didática. Porém, as próprias problematizações e argumentos apresentados pelos estudantes apontam que eles já desenvolvem alguns destes conceitos e que seria possível aprofundá-los a partir de novas sequências didáticas que os ajudassem a entender as diferenças entre os conceitos de organização e produção do espaço. 


\subsection{SITUAÇÃO DE APRENDIZAGEM 5: A Geografia: uma lente para ler o mundo}

MAPA CONCEITUAL: SITUAÇÃO DE APRENDIZAGEM 5- A Geografia: uma lente para ler o mundo.

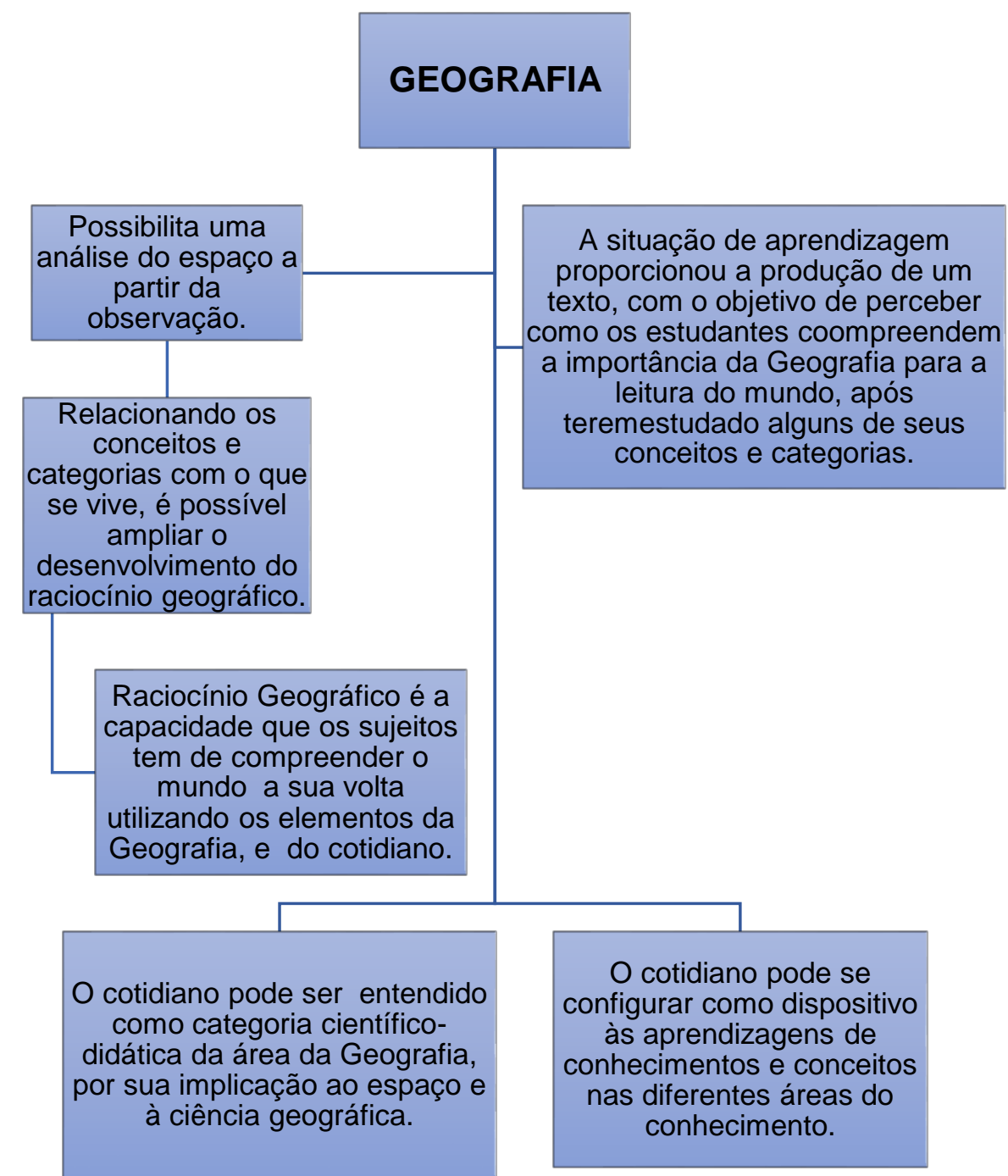

A Situação de aprendizagem abaixo tem o objetivo de finalizar a pesquisa.

Dessa forma ela é uma reflexão acerca dos raciocínios geográficos que estão presente na vida dos estudantes e as potencialidades que este conhecimento fornece a eles na leitura do mundo, iniciando pelo lugar e articulando diferentes escalas espaço-temporais, bem como suas representações através da linguagem cartográfica. 
Para esta situação de aprendizagem, foi pedido a elaboração de um texto, que deveria conter no mínimo 25 linhas, respondendo o seguinte questionamento: de que maneira a Geografia me ajuda a compreender o mundo?

A partir de produções textuais, a análise foi feita, buscando encontrar nas respostas aquilo que no decorrer desta dissertação conceituamos como raciocínio geográfico, que é a capacidade de articulação dos conceitos geográficos, com suas experiências vividas de modo a criar raciocínios que os ajudem a se desenvolver como sujeitos críticos a partir da leitura do mundo em suas diferentes escalas espaço-temporais.

Para tanto foram selecionados alguns trechos dos textos, para que fosse possível uma reflexão sobre os resultados obtidos.

"A Geografia me ajudou a entender que existem paisagens
diferentes na cidade, por causa das diferenças de salários das
pessoas, que acabam fazendo elas terem condições
desiguais".(Aluno 1- $6^{\circ}$ ANO A)

O trecho acima é capaz de informar que o sujeito consegue ler a paisagem da cidade e imprimir sobre ela um posicionamento. No argumento do estudante, é possível verificar um primeiro esforço de interpretação das diferentes localizações e distribuição das paisagens na cidade de São Paulo, com a tentativa de correlacionar com as desigualdades de renda na cidade.

A partir desta compreensão, pode-se afirmar então, que o aluno vai percebendo as várias nuances que a paisagem apresenta e sua leitura do espaço vai se tornando mais compreensível, em uma dimensão mais concreto e com sentido. Outro trecho bastante interessante retirado de um texto de outro estudante foi o seguinte: 
"Os mapas são a linguagem da Geografia, eles nos ajudam a enxergar o mundo, em uma escala menor, o que facilita a maneira de aprender a enxergar situações, que não poderiam ser vistas, se não tivesse seu tamanho diminuído"(Aluno 2- $6^{\circ}$ ANO A)

Neste trecho, o estudante expressa a importância da linguagem cartográfica na compreensão de fenômenos, ressaltando que os mapas e os outros recursos que a cartografia se utiliza tem uma escala, ou seja, foram reduzidos para tornar possível a sua representação e compreensão. Este trecho revela certa apropriação, pelo estudante, de um dos conceitos fundamentais para a leitura de mapas, a escala, o que pode indicar possível resultado das sequências didáticas desenvolvidas com os estudantes. Em nossa perspectiva, esta constatação, mesmo que parcial, é importante uma vez que se o leitor consegue relacionar conceitos atrelados a sua leitura, pode-se então afirmar que seu conhecimento está de fato acontecendo satisfatoriamente e seu raciocínio geográfico se ampliando.

Outro trecho bastante interessante diz respeito aos problemas urbanos.

"Uma coisa que a Geografia me ajudou a aprender, é porque existem alguns alagamentos, e porque algumas pessoas têm que viver nessas áreas. Isso tem a ver com a altitude do terreno, os rios que cortam aquele bairro, e algumas pessoas só tem dinheiro para comprar suas casas nesses lugares, onde é mais barato, por isso acabam sofrendo as consequências, quando chove, por exemplo, e alaga a casa, e eles perdem tudo."(Aluno 3- $6^{\circ}$ ANO C.)

Observando esse trecho, é possível identificar que o aluno em questão avançou em sua leitura crítica do espaço, e isso só foi possível, porque ela compreendeu os conceitos, e conseguiu relacioná-los com a realidade da cidade em que vivem. O trecho mencionado tem muita relação com a situação de 
aprendizagem 4, onde eles conseguiram enxergar a cidade em que vivem, primeiro através do mapa, e depois através da pesquisa, que fez com que eles visualizassem os lugares que estavam presentes na representação. No argumento apresentado pelo estudante é possível ver a construção de correlação mais complexas (mais de duas variáveis) entre fenômenos espaciais para a elaboração de interpretações da realidade. No caso específico, o estudante correlacionou aspectos naturais com elementos sociais na construção de seu argumento, o que revela maior profundidade interpretativa da realidade um raciocínio geográfico cada vez mais complexo, uma vez que expressa entendimento da relação entre localização, distribuição e correlação de fenômenos espaciais.

Dessa forma, pensar a sala de aula como um espaço de aprendizagem cotidiana, é também perceber, que a Geografia pode ser uma fonte de inspiração para que o conhecimento não seja visto como um bloco imóvel, mas algo que está em constante movimento, nos acompanhando na nossa trajetória e nos ajudando a ler o lugar que pertencemos. Fortalecendo assim, o que diz Cavalcanti $(2010$, p.7),

[...] ensinar Geografia não é ensinar um conjunto de conteúdos e temas, mas é, antes de tudo, ensinar um modo específico de pensar, de perceber a realidade. Trata-se de ensinar um modo de pensar geográfico, um olhar geográfico, um raciocínio geográfico. Esse modo de pensar tem sido estruturado historicamente por um conjunto de categorias, conceitos e teorias sobre o espaço e sobre a relação da sociedade com o espaço.

Dessa forma, pode-se então afirmar, que pensar geograficamente resulta na mobilização de conceitos e estratégias, que vão sendo construídas na vida do sujeito, e se ampliando quando aprende conceitos geográficos. Um trecho que despertou bastante atenção, foi esse: "A geografia me ajuda a descobrir a minha cidade porque ela é muito difícil de entender" (Aluno 4- $6^{\circ}$ ANO B).

Aqui, é possível perceber que o sujeito tem dificuldades de entender a cidade, tendo em vista que ela é realmente complexa, e sua leitura não se dá de maneira simplificada. A Geografia, para ele, auxilia na descoberta da cidade, aprendendo a ler o que está presente nela, a partir também das 
experiências vividas no lugar onde mora. A partir desse aprender, consegue, criticamente ler o mundo, não importando a forma como este mundo está sendo representado, se através de um texto, ou através de um mapa. O objetivo é cumprido: ler o mundo e pensar sua lógica através do viés geográfico.

Outro aluno apresentou a seguinte questão: "Ler o mapa é difícil, não sei qual é o tema ou qual é o título, e me perco". ( Aluno 5- 6 ${ }^{\circ}$ ANO C). Neste caso é possível perceber que em alguns casos a cartografia formal, não atinge todas os sujeitos da mesma forma. Essa fala reforça a dificuldade que ele tem de separar o grande tema que envolve o que está sendo representado, e seu título, que é um recorte do fenômeno.

Diante desta questão, é importante repensar a maneira de levar a esses sujeitos a cartografia oficial, dando-Ihes as possibilidades de enxergar os elementos do mapa, pois são essenciais neste processo de alfabetização cartográfica. Ao passo que eles apresentam dificuldades em separar tema e título, alguns conseguem fazer reflexões sobre o tema quando ele é desvelado, mostrando, que mesmo não fazendo a leitura técnica ele consegue raciocinar geograficamente e refletir sobre algumas questões, e isso não pode ser desconsiderado no processo. Assim, retomar o conceito, usando por exemplo algum tema cotidiano, que pode auxiliá-lo a entender melhor esses elementos do mapa pode ser um canal para facilitar a aprendizagem e colaborar na alfabetização cartográfica dele.

Essa atividade apontou que alguns estudantes pesquisados, apresentaram algumas dificuldades na leitura do mapa, e isso não implicou necessariamente em dificuldades no desenvolvimento do raciocínio geográfico. Diante destas respostas, é possível perceber que a relação entre cartografia e raciocínio geográfico é dialética. Ou seja, a alfabetização cartográfica não antecede o raciocínio geográfico, ela é uma das mediações possíveis para construção do raciocínio geográfico, assim como o raciocínio geográfico contribui para que o estudante se aproprie de forma crítica da cartografia como linguagem.

Isso reforça a ideia inicial da pesquisa, que é a de que os raciocínios em torno da Geografia estão presentes na vida dos sujeitos independente da escola, mas é através da escola e das categorias, conceitos e linguagens da Geografia 
que esses conhecimentos são ampliados, trazendo-lhes mais possibilidades de leitura do mundo. Assim é possível também perceber que alguns alunos conseguiram, dentro de suas realidades, perceber a importância da Geografia para a leitura do mundo, mesmo apresentando dificuldades no processo de alfabetização cartográfica.

Um dos pontos frágeis desta última atividade foi não conseguirmos avançar, de forma sistemática, no processo de avaliação dos diferentes raciocínios geográficos desenvolvidos pelos estudantes. Apesar de termos colocado com um dos principais desafios das atividades propostas, diálogo com as pesquisas recentes produzidas sobre o tema, encontramos uma série de dificuldades, tanto no planejamento, como na organização e desenvolvimento das atividades, que impossibilitou este trabalho de sistematização e que, em nossa perspectiva, fragilizou os resultados aqui apresentados. Em certa medida, o cotidiano do trabalho docente na rede estadual, com pouco ou nenhum tempo para a reflexão sobre e a partir da prática, bem como ausência de tempos para preparação qualitativa das ações didáticas pode ser uma das causas para esta dificuldade. Outra consiste em nossa própria dificuldade de conceituar e criar instrumentos de avaliação que possibilitassem o entendimento dos raciocínios geográficos elaborados pelos estudantes. Tal conceitualização foi se dando no decorrer do desenvolvimento da pesquisa e das situações didáticas, resultando de um processo de reflexão sobre e partir da prática. Este aprender refletindo e agindo, no entanto, nos dificultou, pelos limites impostos pelo tempo da pesquisa, na recriação e reaplicação das sequências.

No entanto, destarte a fragilidade dos resultados aqui apresentado, destacamos a importância das reflexões produzidas a partir da pesquisa em nosso processo formativo. Como docente em início de carreira, diante de uma situação cotidiana de precarização das condições de formação continuada oferecida pela rede estadual, o tempo-espaço desta pesquisa foi fundamental para o entendimento de conceitos, processos e ações centrais no ensinoaprendizagem e geografia. Se as situações de aprendizagem parecem ainda frágeis em sua proposição e execução, os resultados delas são fundamentais em termos de entendimento do pesquisador em relação a sua profissão e a disciplina que leciona. 


\section{CONSIDERAÇÕES FINAIS}

O trabalho aqui apresentado é fruto de uma pesquisa que foi realizada em minhas aulas de Geografia na rede estadual. Olhar para o seu trabalho, refletir sobre ele e buscar estratégias para melhorar sua prática é um desafio. A práxis, que é,

[...] a atividade concreta pela qual os sujeitos humanos se afirmam no mundo, modificando a realidade objetiva e, para poderem alterá-la, transformando-se a si mesmos. É a ação que, para se aprofundar de maneira mais consequente, precisa da reflexão, do autoquestionamento, da teoria; e é a teoria que remete à ação, que enfrenta o desafio de verificar seus acertos e desacertos, cotejando-os com a prática (KONDER, 1992, p. 115).

Tudo isso faz com que a teoria e a prática sejam elementos inesperáveis. Eles se são essenciais e se completam, pois se não houver uma reflexão filosófica, a prática se torna vazia, e perde suas potencialidades como elemento de desenvolvimentos dos sujeitos.

Neste sentido, pensar a linguagem cartográfica como caminho para o desenvolvimento do raciocínio geográfico em meio ao cotidiano da sala de aula foi um trabalho que exigiu reflexões e ações cotidianas, que levaram a um amadurecimento da minha prática docente.

Elaborar atividades que fossem capazes de estimular o pensar geográfico e articular isso com os conceitos que se aprende em Geografia foi uma tarefa que exigiu bastante observação e cuidado, pois, ao final, elas seriam utilizadas como instrumentos da pesquisa.

Olhar para as potencialidades do ensino de Geografia aliado a cartografia, foi uma tarefa de extrema importância no processo de construção teórica deste estudo, pois ajudou a compreender que a ciência geográfica, dentro da sala de aula, se torna desveladora de visões de mundo e auxilia na compreensão do que está posto para os sujeitos.

Essa visão de mundo que a Geografia permite termos só é concebida se o sujeito conseguir desenvolver os conceitos que são trabalhados diariamente na sala de aula. Por sua vez, tais conceitos precisam estar atrelados a situações 
cotidianas, para que eles consigam se familiarizar com eles, e utilizá-los em seus cotidianos.

A escolha do ciclo/série para a elaboração da pesquisa tem relação direta com a minha prática docente. Antes mesmo de me colocar a estudar os currículos, já trabalhava com o sexto ano do ensino fundamental II desde o início da docência. A maneira como a cartografia era tratada me despertou mais desejo por compreender seus caminhos e, assim, focar a pesquisa nessa linguagem, e como ela poderia colaborar com o desenvolvimento do raciocínio geográfico.

Cada uma das atividades que foram aplicadas entre maio e outubro de 2019, foi importante para ajudar a traçar os caminhos que seriam seguidos para chegar nesse objetivo, que era ajudar os alunos a raciocinar geograficamente dentro de suas realidades, e enxergar a linguagem cartográfica como sua aliada neste processo de enxergar o mundo pelo viés geográfico. Gostaríamos, aqui, de sistematizar as principais considerações decorrentes as situações desenvolvidas nesta pesquisa.

Em primeiro lugar, gostaríamos de destacar que as situações reforçaram uma das premissas fundantes desta pesquisa: os estudantes já desenvolvem raciocínios geográficos antes de entrarem na escola. Em todas as situações, foi possível verificar que os estudantes construíam suas hipóteses e argumentos para entender os desafios e problemas propostos a partir de suas vivências. Com isso, já apresentavam entendimento sobre a localização e a distribuição dos fenômenos espaciais, inclusive com certo grau de correlação. Com o desenvolvimento das situações de aprendizagem, mediadas pela linguagem cartográfica, foi possível perceber que muitos estudantes conseguiram construir interpretações mais complexas da realidade, correlacionando mais de duas variáveis e utilizando conceitos geográficos, como paisagem, escala, entre outros.

Tal processo demonstrou a importante da escola e do ensino de geografia na ampliação dos raciocínios geográficos elaborados pelos estudantes. Em nossa perspectiva, um dos elementos fundamentais para esta ampliação está relacionado a criação de mediação de didáticas que possibilitem aos estudantes, de um lado, se apropriarem de conceitos e linguagens da geografia e, de outro, construindo argumentos que correlacionem múltiplas variáveis e articulem diferentes escalas espaço-temporais. Em nossa visão, estes dois elementos são 
os desafios para que os estudantes possam desenvolver raciocínios geográficos mais complexões durante o seu processo de escolarização na educação na educação básica.

O segundo aspecto que gostaríamos de destacar como resultado da pesquisa diz respeito ao fato de que raciocínio geográfico e a cartografia escolar mantem uma relação dialética e não dual. Para desenvolver raciocínios geográficos os estudantes não precisam, necessariamente, dominar todos os conceitos e elementos da cartografia oficial, o que levaria, como ainda vemos em muitas propostas curriculares, uma lógica linear que coloca a cartografia como um conteúdo a ser trabalhado como preparatório aos outros conteúdos da geografia. Em nossa perspectiva, essa relação dialética entre raciocínio geográfico e cartografia escolar pressupõe reafirmar a cartografia como linguagem e, portanto, mediação essencial em todos os processos de ensinoaprendizagem em geografia. A apropriação da linguagem cartográfica contribui para o desenvolvimento de raciocínios geográficos mais complexos que, por sua vez, possibilitam novas apropriações e usos da linguagem cartográfica.

Como dissemos no capítulo anterior, uma das principais fragilidades desta pesquisa diz respeito a construção e sistematização de instrumentos de avaliação que possibilitassem o entendimento dos raciocínios geográficos desenvolvidos pelos estudantes durante a pesquisa. Não retornaremos aos motivos que apontamos para esta dificuldade. Cabe, apenas, ressaltar que este é um dos principais desafios que nos colocamos como professorespesquisadores para futuras investigações e para a nossa ação cotidiana na escola pública.

Este trabalho nunca teve a pretensão de apresentar respostas fechadas ou soluções definitivas sobre o tema, uma vez que partimos do pressuposto da importância do cotidiano e do trabalho docente a partir da reflexão sobre sua própria prática. O que fica patente desta investigação e que aqui reafirmamos é o sentido da cartografia escolar como uma das linguagens fundamentais para 0 desenvolvimento do raciocínio geográfico. Por isso, ela deve estar presente nas práticas em sala de aula, pois permeia todos os momentos de aprendizagem, dando condições aos sujeitos de enxergarem a si e a realidade, de forma cada vez mais complexa. No entanto, cartografia e raciocínio geográfico são conceitos. O que os anima, o que os coloca em movimento, é sentido da relação 
pedagógica, fundada entre docente, discentes e a realidade. E é ela que precisa estar no centro de todo projeto de educação que se queira emancipador.

\section{REFERÊNCIAS}

ALMEIDA, R. D. de., PASSINI, E. Y. O espaço geográfico: ensino e representação. São Paulo: Contexto. 1999. 7 ed.

ANDRÉ, M. E. D. A. Estudo de caso: seu potencial na educação. Cadernos de Pesquisa: revista de estudo e pesquisa em educação, São Paulo, v. 49, p. 51-54, maio 1984.

ASCENÇÃO, Valéria de Oliveira Roque; SILVA, Patrícia Assis da; Valadão Roberto Célio. Do uso pedagógico dos mapas ao exercício do Raciocínio Geográfico. Boletim Paulista de Geografia, v. 99, 2018, p.34-51.

ASSIS, Francisco de; COSTA, Franklin Roberta da; LIMA, Fernandes. A linguagem cartográfica e o ensino-aprendizagem da Geografia: algumas reflexões. Geografia Ensino \& Pesquisa, vol. 16, n. 2, maio/ ago. 2012.

BRABANT, J.F. Crise da Geografia, Crise da Escola. In: OLIVEIRA, A. U. de. (Org.) Para onde vai o ensino de geografia? São Paulo: Contexto, 1989. 
BRANDÃO, Carlos Rodrigues. Pesquisa participante. São Paulo: Brasiliense, 1981.

. Repensando a Pesquisa Participante. São Paulo, Brasiliense, 1985.

BRASIL, Parâmetros Curriculares Nacionais. Geografia / Secretaria de Educação Fundamental. Brasília 1997.

BRASIL. Ministério da Educação. Base Nacional Comum Curricular. Versão definitiva. Brasília: MEC, 2017. Disponível em: Acesso em: 12 de jul. de 2017.

BONILLA, M. H.; ASSIS, A. Tecnologia e novas educações. In: FAEEBA: Educação e Contemporaneidade. Salvador, v.14, n.23,p.15-27, Jan/Jun 2005.

CALLAI, H. Estudar o lugar para compreender o mundo. In: CASTROGIOVANNI, A. C. (Org.). Ensino de geografia: práticas e textualizações no cotidiano. Porto Alegre: Mediação, 2000.

CAÑAS, A. J.; NOVAK, J. D. e REISKA, P. How good is my concept map? Am I a good Cmapper? Knowledge Management \& E-learning, 7(1), 2015. p. 619.

CARLOS, Ana Fani A. A Cidade. São Paulo;Contexto,2001.

CARVALHO, D. de. O ensino de geografia no curso de humanidades. Boletim Geográfico, ano I, № 10, janeiro de 1944.

. O sentido geográfico. Boletim Geográfico, ano III, ํㅡㄹ, abril de 1945.

CASAL, A. de. Corografia Brasilica. São Paulo: Edições Cultura, 1943. 
CAVALCANTI, Lana de Souza, A geografia e a cidade: Ensaios sobre o ensino de geografia para a vida urbana cotidiana. Campinas, SP: Papirus, 2008.

O Ensino de Geografia na Escola. Campinas,

Sp. Papirus, 2012.

CLAVAL, PAUL. Terra dos Homens: a geografia; tradução - Domitila Madureira. São Paulo: Contexto, 2010.

FRANCISCHETT, Mafalda Nesi. A cartografia no ensino -aprendizagem da Geografia.Disponível em: <http://www.bocc.ubi.pt/pag/francischett-mafaldarepresentacoes-cartograficas.pdf>. Acesso em: 12 dez 2017.

G1.globo.com/sp/sao-paulo/noticia/2019/03/03/chuva-deixa-regioes-dacidade-de-sao-paulo-em-estado-de-atencao-neste-domingo.ghtml/ Acesso em 20 de junho de 2019.

GARCIA, R.L. \& MOREIRA, A.F.B.(orgs). Currículo na contemporaneidade incertezas e desafios. São Paulo, 2003, Ed. Cortez.

GIROTTO,E. D.; MORMUL,N. M. Formação Docente e Educação Geográfica: entre a escola e a universidade.Curitiba: CRV, 2016.

GIROTTO, E.D. Escola, lugar e democracia: a construção da esfera pública e o direito à cidade na periferia paulista. GARCIA, P. S. (Org.) Debates e contribuições sobre a escola pública: de professor para professor. São Paulo: LCTE Editora, 2009.

GIROTTO, Eduardo Donizeti. Ensino de Geografia e Raciocínio Geográfico: as contribuições de Pistrak para a superação da dicotomia curricular. Campinas: Revista Brasileira de Educação em Geografia, 2015. 71-86 p. 5 v. 
GIROTTO, Eduardo Donizeti; MORETTO, Beatriz Campos. Entre a escola e a universidade: os múltiplos sentidos do trabalho de campo como mediação didática. Geotextos, Bahia, v. 2, n. 13, p.91-114, dez. 2017.

GOODSON, Y. A construção social do currículo. Lisboa: EDUCA, 1997.

GOMES, Paulo Cesar da Costa. Quadros Geográficos: Uma forma de ver, uma forma de pensar. Rio de Janeiro: Bertrand Brasil Ed, 2017.

GUIMARÃES, I. V. (2018). Ensinar e aprender Geografia na Base Nacional Comum Curricular (BNCC). Ensino Em Re-Vista, 25(4), 1036-1055. https://doi.org/10.14393/ER-v25n3e2018-11. Acesso em: 26 MAIO. 2019.

JAQUES, Jonatha Liprandi; SOUZA, Silvanei Alves de; SILVA, Igor Comério da. Potencializando o raciocínio geográfico docente com a cartografia escolar. Revista de Ensino de Geografia, Uberlândia, v. 7, n. 13, p. 127-145, jul./dez. 2016.

JOHNSON, Steven. O Mapa Fantasma: como a luta de dois homens contra o cólera mudou o destino de nossas metrópoles. Rio de Janeiro: Zahar Ed., 2008.

JOLY, Fernand. A Cartografia. Campinas: Papirus,1990.

KATUTA, A. M. Uso de mapas = alfabetização cartográfica e/ou leiturização cartográfica? Nuances: Revista do curso de pedagogia, Presidente Prudente.1997.

KOEMAN, Cornelis. O Princípio da Comunicação na Cartografia. São Paulo: USP/ FFLCH - Departamento de Geografia - Grupo de Estudos em Cartografia Temática - GECART (Série Geocartografia, 5), 1995.

LA BLACHE, P. V. de. A geografia na escola primária. Boletim do Conselho Nacional de Geografia, Ano 1, oㅜ 1, Rio de Janeiro, abril de 1943 
LACOSTE, Yves. A Geografia - isso serve, em primeiro lugar, para fazer a guerra. Tradução Maria Cecília França. Campinas: Papirus, 1988.

LIMA JR, Arnaud S. de. Tecnologias Inteligentes e Educação: Currículo Hipertextual. Rio de Janeiro: Quartel, 2005.

LOCH, R. E. N. e FUKNER, M. .A Linguagem Cartográfica e o ensino de Geografia: um panorama de Santa Catarina. Relatório de Pesquisa. Florianópolis.2004.

MARTINELLI, M. A Sistematização da Cartografia Temática. ALMEIDA, R.D.de (Org.) Cartografia Escolar. São Paulo: Contexto.2008.

OLIVEIRA, Lívia de. Estudo Metodológico e Cognitivo do Mapa. In: Cartografia Escolar. ALMEIDA, Rosângela Doin de, (org). São Paulo: Contexto, 2007.

PASSINI, Elza Yassuko. Alfabetização Cartográfica e a Aprendizagem em Geografia./ Colaboração Romão Passini. 1 Ed. São Paulo. Cortez.2012.

PETCHENIK, Bárbara Bartz. Cognição e cartografia. Geocartografia. n.6, São Paulo:USP,1995.

PIAGET, Jean. Para onde vai a educação. Lisboa: Livros Horizonte, 1978.

PONTUSCHKA, N. N. Geografia, representações sociais e escola pública. Terra Livre, São Paulo, № 15, 2000.

Para ensinar e aprender Geografia.1.ed. São Paulo:

Cortez, 2007. 
RICHTER, Denis. Linguagem cartográfica no ensino em Geografia. Revista Brasileira de Educação em Geografia, Campinas, v. 7, n. 13, p. 277-300, jan./jun., 2017.

SANTOS, M. Técnica Espaço Tempo: Globalização e meio técnico-científico informacional. São Paulo: Hucitec, 1998. . Por uma Geografia nova. São Paulo: Hucitec/EDUSP, 1978.

.Metamorfoses do Espaço Habitado, HUCITEC, São Paulo, 1988.

SÃO PAULO. Currículo do Estado de São Paulo: Ciências Humanas e suas tecnologias, coord.Maria Inês Fini. São Paulo: SEE, 2010.

SEEMANN, Jörn. Mapas e Percepção Ambiental: do Mental ao Material e viceversa. Rio Claro. 2003.

.Subvertendo a Cartografia escolar no Brasil. Revista Geografares, n¹2, p.138-174, julho, 2012, ISSN 2175 -370.

SIMIELLI, M. E. R., Cartografia no ensino fundamental e médio. In: CARLOS, A. F. A. (org). A Geografia na sala de aula. 8 ed. São Paulo: Contexto, 2007.

SOUZA, José Gilberto, KATUTA, Ângela Massumi. Geografia e conhecimentos cartográficos: A cartografia no movimento da geografia brasileira e a importância do uso de mapas.São Paulo. Editora UNESP, 2001.

THIOLLENT. Michel. Metodologia da pesquisa-ação. 12a ed. São Paulo: Cortez, 2003.

YIN, R. K. Estudo de caso: planejamento e métodos. 2 ed. Porto Alegre: Bookman, 2001. 